NBSIR 80-2085

\title{
Fire Performance of Loose Fill Cellulosic Insulation in Residential Occupancies - A Progress Report
}

Lionel A. Issen

Center for Fire Research National Engineering Laboratory National Bureau of Standards U.S. Department of Commerce

Washington, D.C. 20234

August 1980

Interim Report

Sponsored in part by:

QC
$100 \quad$ ashington, D.C. 20585

.456

$80-2085$

1980

c. 2 

m

\section{FIRE PERFORMANCE OF LOOSE FILL \\ CELLULOSIC INSULATION IN RESIDENTIAL OCCUPANCIES - A PROGRESS REPORT}

Lionel A. Issen

Center for Fire Research

National Engineering Laboratory

National Bureau of Standards

U.S. Department of Commerce

Washington, D.C. 20234

August 1980

Interim Report

Sponsornd in part by:

Department of Energy

Washington, D.C. 20585

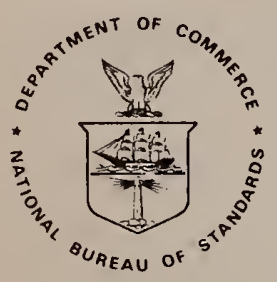

U.S. DEPARTMENT OF COMMERCE, Philip M. Klutznick, Secręary Luther H. Hodges, Jr., Deputy Secretary Jordan J. Baruch, Assistant Secretary for Productivity. Technology, and Innovation NATIONAL BUREAU OF STANDARDS, Ernest Ambler, Director 


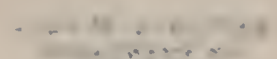

$+1 .$.

1 + : 
LIST OF TABLES . . . . . . . . . . . . . . . . . . . iv

LIST OF FIGURES . . . . . . . . . . . . . . . . . . . . v v

LIST OF SYMBOLS . . . . . . . . . . . . . . . . . . . vi vi

Abstract . . . . . . . . . . . . . . . . . . 1

1. INTRODUCTION . . . . . . . . . . . . . . . . 2

2. LABORATORY TESTS FOR CELLULOSIC INSULATION . . . . . . . . . 4

2.1 Recessed Light Fixture Test . . . . . . . . . . . 4

2.2 Divided Box Test . . . . . . . . . . . . . . . 4

2.3 Improved Smoldering Tests . . . . . . . . . . . 5

3. FIRE RETARDANTS . . . . . . . . . . . . . . . 6

4. EXPERIMENTAL RESULTS . . . . . . . . . . . . . . . . 7

4.1 Smolder Tests (HH-I-515D) . . . . . . . . . . . 8

4.2 Attic Floor Radiant Panel Tests (HH-I-515D) . . . . . . . 9

4.3 Recessed Light Fixture Test . . . . . . . . . . . . . 9

4.4 Divided Box Smoldering Test . . . . . . . . . . . . . 9

4.5 Smolder Property Tests . . . . . . . . . . . 10

5. DISCUSSION . . . . . . . . . . . . . . . . . 11

6. CONCLUSIONS . . . . . . . . . . . . . . . . 12

7. RECOMMENDATIONS . . . . . . . . . . . . . . . 13

8. ACKNOWLEDGMENTS . . . . . . . . . . . . . . . 13

9. REFERENCES . . . . . . . . . . . . . . . . 13

APPENDIX A. CRITERIA FOR TIME OF SMOLDERING TESTS . . . . . . . A-1

APPENDIX B. RELATIONSHIP BETWEEN HOT PLATE TEST

AND ADIABATIC FURNACE . . . . . . . . . . . . B-1 


\section{LIST OF TABLES}

Page

Table 1. Results of smolder tests HH-I-515D . . . . . . . . 16

Table 2. Commercial insulation - recessed light fixture test . . 17

Table 3. Laboratory insulation - recessed light fixture test . . 18

Table 4. Summary of experimental data - commercial cellulosic insulations . . . . . . . . . . . . . . . 19

Table 5. Summary of experimental data - laboratory cellulosic insulations . . . . . . . . . . . . . 20 
Figure 1. Cigarette smoldering test . . . . . . . . . . . 22

Figure 2. Recessed light fixture test exterior view . . . . . . . 22

Figure 3. Recessed light fixture test interior view . . . . . . 23

Figure 4. Divided box test . . . . . . . . . . . 23

Figure 5. Blower mixer for preparing laboratory insulations . . . 24

Figure 6. Average particle size distribution of boric acid and borax................. 25

Figure 7. Effect of borax and boric acid on weight loss -smoldering ignition............... 26

Figure 8. Effect of borax and boric acid and fineness of grind on critical radiant flux -- attic floor radiant panel . . . . . . . . . . . . . . .

Figure 9. Divided box test -- maximum temperature vs \% chemical by weight of mix for different grinds of boric acid . .

Figure 10. Divided box test -- maximum temperature vs \% chemical by weight of mix for polybor ... . . . . . . .

Figure 11. Hot plate tests -- untreated cellulose . . . . . . 30

Figure 12. Adiabatic furnace test -- untreated cellulose . . . . . 31

Figure 13. Comparison of smolder ignition temperatures inferred from adiabatic furnace tests and measured in hot plate tests . . . . . . . . . . . . . . .

Figure A-1. Dimensionless slope vs dimensionless time at hot plate................ A-5

Figure A-2. Surface heat transfer coefficient . . . . . . . . . A-6

Figure A-3. Dimensionless unexposed surface temperature vs dimensionless time .. . . . . . . . . . . . A-7

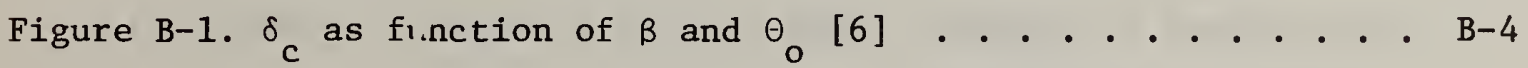

Figure B-2. Correspondence of adiabatic furnace and equivalent hot plate test . . . . . . . . . . . . B B-5 


\section{LIST OF SYMBOLS}

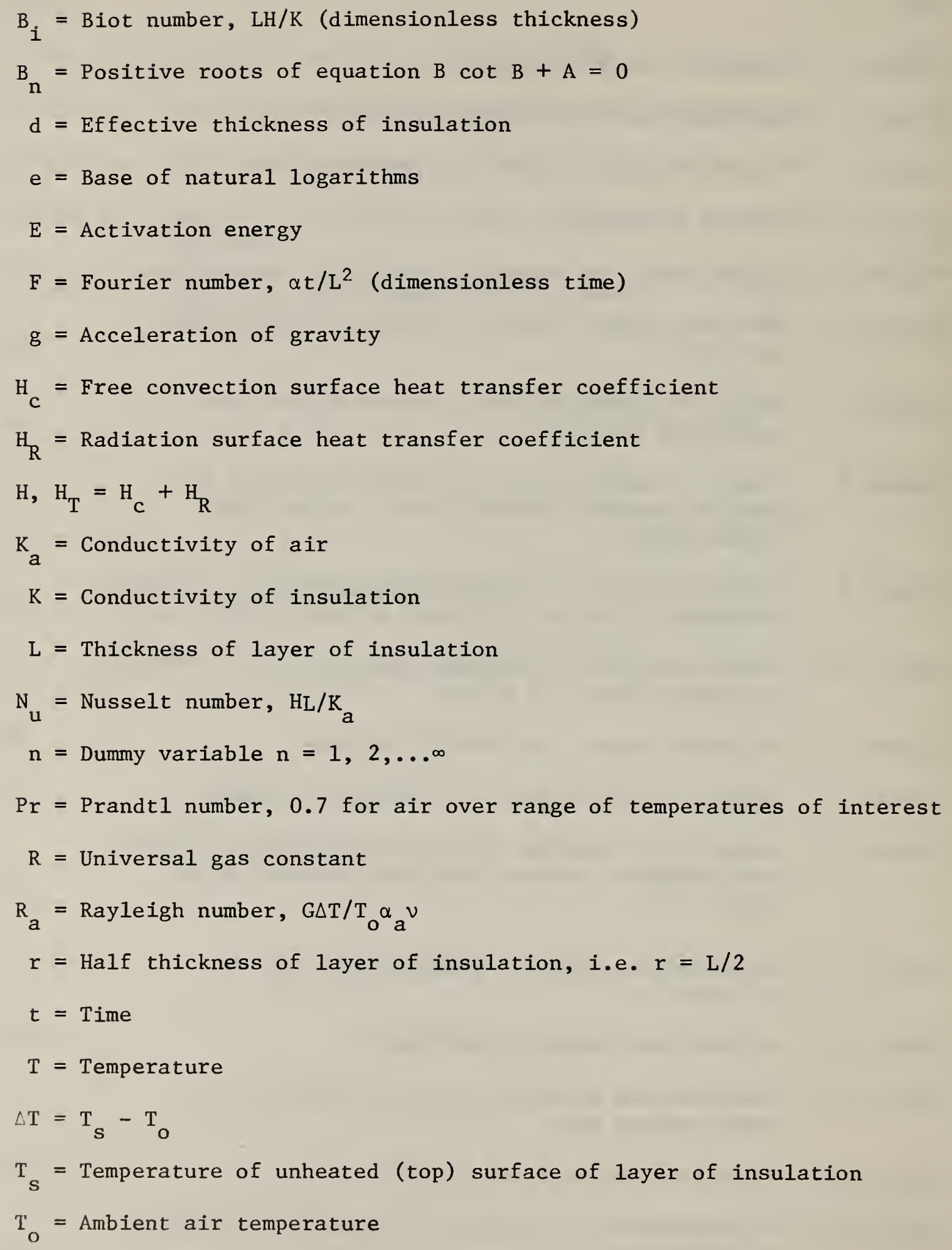




\section{LIST OF SYMBOLS (continued)}

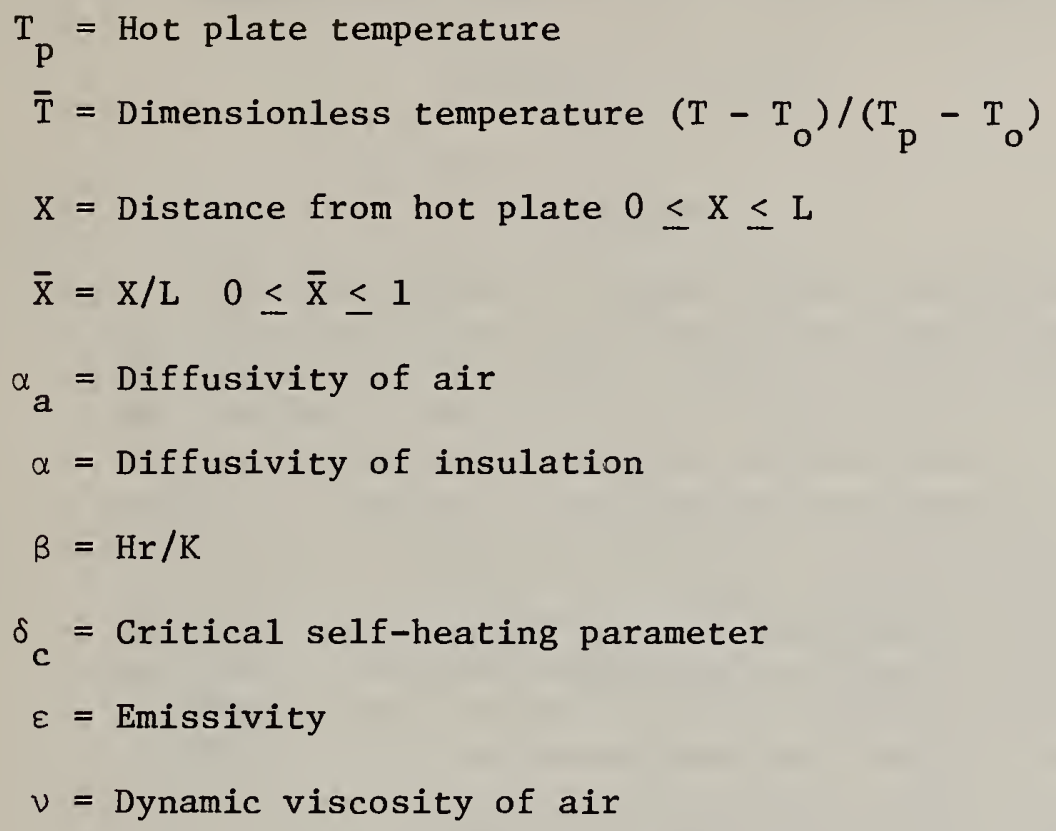



FIRE PERFORMANCE OF LOOSE FILL CELLULOSIC INSULATION IN RESIDENTIAL OCCUPANCIES - A PROGRESS REPORT

Lione1 A. Issen

\section{Abstract}

The smoldering and flame spread properties of cellulosic loose fill insulation were examined as a function of retardant type, particle size, and concentration to provide a basis for the development of improved fire test methods. A series of laboratory insulations was prepared whose fire performance covered an extended range of critical radiant $f 1 u x$ in the attic floor radiant panel test and weight loss in the cigarette smoldering test. These materials were evaluated in a recessed light fixture test in a simulated attic configuration. Borax and boric acid were effective in raising the critical radiant flux (CRF) in the attic floor radiant panel test, but borax alone, in the cigarette smolder test, increased the smoldering potential of loose fill cellulosic insulation. The divided box test for smoldering propagation appears to be a more realistic test than the present test for smoldering ignition.

In the cigarette smoldering test, inclusion of $10 \%$ borax increased the boric acid requirement for passing from $7.5 \%$ to $20 \%$. In the attic floor radiant panel test, the finer the grind, the less boric acid required to meet Federal Specification HH-I-515D. This varied from less than $10 \%$ for vapor applied boric acid to over $35 \%$ for granular boric acid. Above the 25\% level the presence of borax did not significantly affect the CRF level. Passing the recessed light fixture test required a minimum of $30 \%$ impalpable boric acid, or $40 \%$ to $50 \%$ intermediate grind boric acid.

In order to determine fundamental parameters which could be used to characterize smoldering ignition potential, a number of test methods have beell investigated which can be used to determine the pre-exponential factor and the activation energy of ignition reaction. These include the Bowes and Townshend hot plate, thermo-gravimetric analysis (TGA), and the adiabatic furnace. 
Key words: Activation energy; borax; boric acid; cellulose; critical radiant flux; fire; fire retardants; fire tests; loose fill insulation; smoldering ignition; thermal analysis; thermal insulation.

\section{INTRODUCTION}

This report covers some of the activities to date at NBS on the fire performance of loose fill thermal insulation as used in residential occupancies. This effort was concentrated on an examination of the smoldering and flame spread properties of loose fill cellulosic insulation in order to establish a technical basis for the development of new test methods.

Since the energy crisis of 1973 there has been a markedly increased use of insulation for both new and existing construction. This increased use has resulted in fire incidents and has uncovered inadequacies in the fire safety requirements and omissions in our understanding of the unique fire behavior that may be associated with the use of these materials.

The work reported here does not address other aspects associated with the introduction of retardants into cellulosic loose fill insulation, e.g., reduced thermal resistance, corrosiveness, fungal growth, mechanical separation, leaching and subliming. The work reported is restricted to the fire properties, in particular the smolder properties and the effect on them of chemical additives.

A number of fires have occurred in which cellulosic loose fill insulation has been the first material ignited. These were mostly attic fires usually started by contact with a recessed light fixture, although a few fires involved other insulations and other heat sources. On September 8, 1978 the Consumer Product Safety Commission (CPSC) required that all insulation manufactured and sold in the U.S. have a flame spread classification not to exceed 25 by the ASTM E84 tunnel test [1] ${ }^{1}$. This test is a flame spread test and the results have no relation to smoldering resistance. Furthermore, the tunnel measures the flame spread on the underside of a ceiling mounting, while in reality flame spread occurs on the upper surface of a floor mounting. In order to overcome the limitations of the tunnel test in evaluating the fire performance of insulations, in 1977 the Center for Fire Research suggested that two different tests be used to evaluate the fire performance of insulations for the Federal purchase specification; these were the attic floor radiant panel test [2] and the cigarette smoldering combustion test [2]. The attic floor radiant panel test simulates conditions on the floor of an attic where insulation may be exposed to thermal radiation from the underside of the roof and accidently exposed to a small flame source. The smoldering test was developed to indicate the

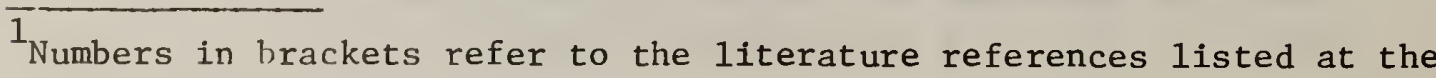
end of this report. 
potential of an insulation to smolder when exposed to a local high temperature source. These tests have now been incorporated by CPSC in the Interim Safety Standard for cellulosic insulation covering insulation manufactured after October 15, 1979.

An important consideration for the suitability of a laboratory test for smoldering combustion would be its ability to predict the smoldering potential of an insulation material as a function of thickness and density when it is exposed to heated surfaces at various temperatures, in particular its ability to predict the occurrence of ignition and continued spread of smoldering when the material is in proximity to a recessed light fixture or a hot flue. In studying the smoldering phenomenon and in evaluating the suitability of a test method, it is necessary to examine a range of materials that range from those that will not smolder to those that will smolder easily.

The smoldering test which is described in HH-I-515D and which is shown in figure 1 requires only simple equipment and a lighted cigarette to run. In this test, the material is placed in a stainless steel box $8 \times 8 \times 4$ in high $(20 \times 20 \times 10 \mathrm{~cm})$. A standard cigarette with the lit end up is placed in a preformed hole at the proximate center of the material. The material passes if the weight loss due to smoldering is 15 percent or less. During the development of this test it was noted that insulations that had passed the ASTM E84 tunnel test with flame spread classifications of 25 or less frequently failed this test. The reason was that the fire-retardant chemicals used were flame inhibitors and not smolder inhibitors.

While the requirement that an insulation must pass the cigarette ignition test reduces the probability of smoldering, it does not eliminate it under all circumstances. The fact that the insulation passes the cigarette ignition test is no guarantee that the insulation will not begin to smolder after prolonged exposure to an extended area heated surface. It is necessary to provide a more realistic test for smoldering ignition and propagation if loose fill cellulosic insulation is to be used safely. Ideally, this should be a property test which could be used to predict the smoldering potential of a material under different exposure and use conditions rather than simply a pass/fail test. This report describes some experiments which provide part of the background needed to develop such a test. It involves an examination of the effect of retardant type, concentration, and particle size on the smoldering properties of loose fill cellulose insulation under realistic conditions. While some of the early experiments were performed with the test methods referenced in HH-I-515D, the intent of the work is neither to verify nor modify the present test methods but to provide part of the background necessary for the second generation of fire tests for thermal insulations. 


\section{LABORATORY TESTS FOR CELLULOSIC INSULATION}

\subsection{Recessed Light Fixture Test}

As part of the overall studies of the performance of insulations, a reduced scale attic mock-up with a recessed light fixture in the floor was used to evaluate smoldering ignition under more realistic conditions. The details are shown in figures 2 and 3 . The mock-up was $4 \times 4 \times 2 \mathrm{ft}$ 6 in high $(1.22 \times 1.22 \times 0.76 \mathrm{~m})$. The underside of the roof was lined with $3-1 / 2$ in $(89 \mathrm{~mm})$ foil backed glass fiber insulation. The 1ight fixture which was rated for $100 \mathrm{~W}$ was fitted with a $150 \mathrm{~W}$ light bulb. This $150 \mathrm{~W}$ light bulb represents a size typical of that which may be used in practice. The light fixture itself is an off-the-shelf residential unit ${ }^{2}$. The dimensions of the fixture are $8 \times 8 \times 4$ in high $(20.3 \times 20.3 \times 10.8 \mathrm{~cm})$. The test is run in the following manner: the floor joist spaces are filled with insulation to the required density using a commercial blower; (2) the overhead air space temperature is raised to and maintained at $60^{\circ} \mathrm{C}$; (3) when the overhead air temperature reaches $60^{\circ} \mathrm{C}$, usually in about 1 hour, the electric light in the fixture is turned on. The test is run either until smoldering occurs or for a maximum of 7 hours.

In this test it was noted that smoldering would start in commercial insulations that had passed the smoldering test referenced in HH-I-515D. Hence, the development of a more severe and realistic test for the smoldering potential of thermal insulation appears to be needed.

\subsection{Divided Box Test}

The recessed light fixture test requires a day to set up and a day to run. In order to reduce the number of these tests, a rapid screening test that would identify those insulations that would likely pass or fail the recessed light fixture test was developed for this project. The apparatus, which is shown in figure 4, is called a divided box tester and consists of a stainless stee 1 box $8 \times 8 \times 4$ in $(20 \times 20 \times 10 \mathrm{~cm})$ with a removable barrier in the middle. On one side of the barrier is placed untreated insulation, on the other the insulation material to be tested. A single thermocouple is placed in the insulation being tested with the bead $50 \mathrm{~mm}$ from the barrier and $20 \mathrm{~mm}$ above the base at the centerline of the box. The thermocouple was made of 22 gauge chromel-alumel (type K) material, with the end $25 \mathrm{~mm}$ oriented more or less parallel to the bottom of the box. To run the test: (1) the barrier is placed in the box, (2) untreated insulation is placed in one half of the box to the specified density, and the test insulation (treated) is placed to the specified density in the half with the thermocouple, (3) the barrier is removed, (4) a lit cigarette with the lit end up is placed in the middle of the untreated insulation, and (5) the temperature is monitored until the smoldering ceases or the temperature has reached a maximum and then decreases. The complete test can

\footnotetext{
${ }^{2}$ By coincidence this test is similar to that of the Oklahoma City recessed light fixture tests, in which a $200 \mathrm{~W}$ bulb was placed in a $150 \mathrm{~W}$ fixture [3]. 
be run in about 30 to 60 minutes. If temperatures develop in the test insulation in excess of about $250^{\circ} \mathrm{C}$, it indicates that the material will support the propagation of a smoldering front and the material is considered to have failed.

In these tests the untreated cellulose was placed at a density of $2.2 \mathrm{pcf}\left(35.2 \mathrm{Kg} / \mathrm{m}^{3}\right)$. This was selected on the basis of a nominal total density of $3 \mathrm{pcf}\left(48.1 \mathrm{Kg} / \mathrm{m}^{3}\right)$ for the insulations, less a nominal 25 percent chemical content.

From the testing that has been done, any material that has passed this divided box smolder test has also passed the recessed light fixture test. The converse does not always hold, as materials that have passed the recessed light fixture test may fail the divided box test. Twelve materials were tested in the divided box tester.

\subsection{Improved Smoldering Tests}

The cigarette smoldering test, the recessed light fixture test, and the divided box test are all pass/fail tests. They simulate different scenarios and each provides somewhat different information which is difficult to extrapolate to conditions other than those of the test. An ideal test would provide information that would permit extrapolation of the smoldering performance to other conditions, and could also be used for other types of insulation than cellulose. With this as a guiding principal, several test methods were examined that could provide the fundamental parameters that would permit extrapolation to conditions other than those of the test.

The first candidate test was the hot plate smoldering test. This test was suggested by the work of Rogers, Ohlemiller, and Summerfield [4] at Princeton and is based on the work of Bowes and Townshend [5] and Thomas and Bowes [6]. The test method, which appears deceptively simple, requires that the minimum hot plate temperature to produce smoldering be determined for a number of different thicknesses of insulation. In this work the density of the insulation should also be controlled. With the assumption that the smoldering ignition reactions follow an Arrhenius temperature dependence, the effective pre-exponential factor and activation energy may be calculated. These in turn can, in principle, be used in a thermal ignition theory model to determine whether smoldering is likely to occur under a given set of field conditions.

The difficulties with this method are that the rate of char formation is a function of the heating rate [7], the thickness of the insulation layer, and the air circulating over and through the insulation. The formation of a char layer having different thermal properties than the insulation alters the rate and amount of heat that reaches the uncharred insulation. The ratio between the diameter of the hot plate and the depth of the insulation also affect the rate of char formation. These factors may have caused some of the observed differences in the results for different hot plates and different operators. 
A second candidate test is thermo-gravimetric analysis (TGA). This test is one of a group of thermal analyses [8] and can be used to determine the activation energy; a second test such as differential scanning calorimetry (DSC) can be used to determine the heat of reaction. On some equipment the DSC can be run simultaneously with the TGA test.

A third candidate test is the adiabatic furnace. The adiabatic furnace simulates self heating in an infinitely large mass of insulation. The pre-exponential factor and the activation energy can be derived from the test data [9]. Though the adiabatic furnace that is being used at present requires that the data be reduced manually [10], it could be modified so that the data could be reduced automatically by a minicomputer.

The lowest temperature to cause self-propagating smoldering is undefined; given enough time and thickness of insulation even relatively modest elevated temperatures can lead to self heating. Thus for both the hot plate test and the recessed light fixture test, a criterion is necessary for the time that the test should be run for determining whether self heating will or will not occur. One such criterion was suggested by Ohlemiller for one-dimensional cases [11]. Using the solution for an inert layer heated on one side and losing heat to the atmosphere on the other side (Carslaw and Jaeger [12] case VI page 126), the time for the temperature gradient in the insulation at the hot plate to reach steady state is given approximately by $(\alpha t) / L^{2}<0.5$. For a $10 \mathrm{~cm}$ thick layer this indicates that the test should be run for $1-1 / 2$ to 2 hours; for a $30 \mathrm{~cm}$ thick layer this indicates that the test should be run for 10 to 15 hours. For the recessed light fixture test in which the insulation covers the light fixture to a depth of 5 to 6 in $(12.5$ to $15 \mathrm{~cm}$ ), this criterion would give a reaction time of about 3 hours. In tests with the recessed light fixture at NBS smoldering has occurred after upwards of 5 to 7 hours of heating. In this test the recessed light fixture is surrounded by insulation, and so the assumption of onedimensional heat transfer is violated. Thus some effective thickness should be used, when applying this criterion, which is intermediate between the thickness of the insulation covering the fixture (which gives too short a time) and the total thickness of insulation in the joist space (which gives too long a time). More work needs to be done to define a suitable criterion for duration of smoldering tests. Based on observations of the recessed light fixture test here at NBS, the test should be run for a time at least twice that given by using the thickness of the insulation over the fixture in Ohlemiller's criterion. An analysis of Ohlemiller's criterion is given in appendix A.

\section{FIRE RETARDANTS}

Until recently fire retardants were added to loose fill cellulosic insulation for the purpose of passing the ASTM E84 tunnel test, which is a flame spread test. These fire retardants include, but are not limited to, ammonium sulphate, boric acid, borax, calcium sulfate, aluminum sulfate, and sodium carbonate. In order to control the $\mathrm{pH}$ resulting 
from the use of sulfates, hydrated lime or other buffers are added. Experience has shown that such combinations of fire retardants and buffers may have a low smolder resistance and may not pass a recessed light fixture test or the smolder test of Federal Specification HH-I-515D. For the initial studies described in this report, boric acid and borax were used in the insulations made up specifically for this project. Of al1 the commonly used fire-retardant chemicals, boric acid is the best smolder inhibitor [13-15]. Boric acid and borax are frequently used together in combination at about $20 \%-25 \%$ by weight of the insulation. This generally produces a cellulosic insulation that has a flame spread classification as low as 25 (or less) in the ASTM E84 tunnel test. A particular insulation must, of course, be tested to insure compliance.

With the current commercial technology for cellulose insulations, the fire-retardant chemicals are almost always added as dry crystals or powders and mixed mechanically with the ground paper. Some equipment can mix fairly closely measured quantities of chemicals with the insulation; however, there is no way of guaranteeing that the chemicals will not separate. When several commercial insulations were examined under a microscope, the chemical crystals which ranged in size from about $0.1 \mathrm{~mm}$ to about $0.4 \mathrm{~mm}$ did not appear to adhere to the fibers of cellulose. This observation raises the question of the mechanical separation and migration of crystals to the bottom of the installation space and the effect this may have on the fire performance of the insulation. To overcome this problem, some members of the industry are experimenting with partially wet processes; that is, a small amount of the chemicals are added as a wet spray. Knoepfler et al. [13] have developed a method for adding boric acid to cellulose in a vapor process. At this time the method is not commercially viable, the process is potentially hazardous 3 , and samples evaluated to date have not passed either the recessed light fixture or the divided box test. Though adding fire-retardant chemicals in a water solution might reduce the total amount of chemicals required for a given level of smoldering resistance the added cost of drying the insulation would make cellulose insulation noncompetitive with other materials. Furthermore, it still remains to show that this is more effective than mixing the dry chemicals with the crushed paper.

\section{EXPERIMENTAL RESULTS}

While a number of tests were run with commercial chemically-treated insulations the bulk of the work was conducted with laboratory-prepared specimens consisting of ground newsprint to which known concentrations of retardants were added. The blower/mixer which was used to prepare the test batches is shown in figure 5. It consists of a drum with a cone at one end, a transparent cover at the other, an electric vacuum cleaner motor and connecting hose.

\footnotetext{
3 Methyl and ethyl borates have flash points below $27^{\circ} \mathrm{C}\left(80^{\circ} \mathrm{F}\right)$; triethyl borine has a flash point of $-36^{\circ} \mathrm{C}\left(-32^{\circ} \mathrm{F}\right)$ [16].
} 
Three different grinds or grades of boric acid were used in these tests; these were granular, an intermediate grind that was ground from the granular grade material in a ball mill, and impalpable. One grind of borax was used; this was similar in size to the intermediate grind of boric acid and prepared in the same way. One grind of polybor (disodium octaborate tetrahydrate) was used. The grain size distributions for these materials are shown in figure 6. The ground paper was supplied by a local insulation contractor. Since there are no standards for determining the size of the ground paper, no attempt was made to classify its size. It was noted qualitatively that within a single batch the ground paper seemed to be uniform, but the fineness of the ground paper varied from batch to batch.

After trying several alternatives the following method of preparing the samples was adopted: (1) the mixer/blower machine was cleaned out manually, (2) about 150 grams of untreated ground paper insulation was run through the mixer/blower for about 2 to 3 minutes and this material was discarded, (3) carefully weighed amounts of untreated paper insulation and chemical(s) were hand mixed in the drum of the mixer/blower, (4) the blower/mixer was then run for 1 to 3 minutes, the time depending on whether the batch was sma11 (about 100 grams) or large (about 400 grams), (5) the contents and residue were carefully brushed out into a weighing pail, and (6) the net weight after mixing was checked. If the weight differed by more than 1 percent or 2 percent from the original weight of the ingredients, the material was discarded and a new batch prepared. A certain amount of practice was necessary for efficient operation of the mixer/blower: too little time resulted in hard lumps of paper; too much time resulted in excessive maceration of the paper. It was also found that there was an optimal angle to run the machine which resulted in efficient mixing and fluffing of the insulation.

\subsection{Smolder Tests (HH-I-515D)}

In the cigarette smoldering test, the observed effect of borax was to increase the required amount of boric acid needed to inhibit smoldering. Figure 7 and table 1 show that with 10 percent borax in the mixture, 20 percent boric acid was required to pass, while without any borax, only $7-1 / 2$ percent boric acid was required to pass this test. Note that these percentages are with respect to the overall final weight of the mixture.

The density of the insulations was controlled by: (1) preparing a batch of insulation of the specified composition, (2) carefully weighing out an amount that would fill the smolder box to the required density, and (3) gently placing and compressing the insulation in the smolder box. In these tests the actual rather than the nominal dimensions of each smolder box were used to determine the required weight of insulation. A material that has passed the cigarette smoldering test at a particular density will also pass at all lower densities. Conversely, a material that has failed the cigarette smoldering test at a particular density will fail at all higher densities. 
It should be noted that the sodium in borax, as with all alkali metals, is a catalyst for promoting smoldering [14-16]. This effect of borax on the smolder resistance of boric acid has also been observed by Knoepfler et al. [13] in their work on smoldering of mattresses.

\subsection{Attic Floor Radiant Panel Tests (HH-I-515D)}

The results of the attic floor radiant panel tests are plotted in figure 8 in terms of critical radiant flux versus percent chemical. Even though the data are somewhat limited, the graph clearly shows that the finer the grind of the chemical the lower the amount required for a given critical radiant flux. In figure 8 the least amount of boric acid was required when it was applied as a vapor and the most boric acid was required when it was applied in the granular form. The relative closeness of the data for impalpable grind and intermediate grind boric acid suggests that there may be an optimal fineness of grind. That is, if the grind of the chemicals is coarser than this optimal grind, the material will have a lower critical radiant flux, and if the chemicals are ground much finer than the optimal, then excess energy has been used for grinding the chemicals. The tests with granular boric acid were terminated at the 35 percent level for two reasons: (1) with this grind the chemicals tend to separate out from the cellulose as the amount exceeds about 35 percent, and (2) this grind is not normally used in commercial mixtures but was included to provide a comparison on the effect of grind fineness.

\subsection{Recessed Light Fixture Test}

The data obtained from the recessed light fixture test are shown in table 2 for commercial cellulose insulations and in table 3 for cellulose insulations that were made up in the laboratory.

No commercial cellulosic insulation has consistently passed this test and the experimental insulations indicate that large amounts of chemicals are required to pass. The finer the grind of the fire-retardant chemicals, the lower the smoldering potential. This is shown by the performance of the 30 percent impalpable boric acid insulation which passed, but the 30 percent granular boric acid and the 30 percent intermediate grind insulations both failed. To pass this test $40 \%-50 \%$ of the intermediate grind boric acid is required. The results of the recessed light fixture test strongly suggest that the cigarette smoldering test may not represent a sufficiently severe exposure.

\subsection{Divided Box Smoldering Test}

The divided box test was developed as a screening procedure for the recessed light fixture test. Any material that has passed this test has also passed the recessed light fixture test; the reverse is not always true.

Figure 9 shows maximum temperature reached during smoldering versus percent chemical in the mix for different grinds of boric acid. The effect of chemical fineness is shown in this figure where 35 percent 
impalpable boric acid ( 85 percent passing 325 mesh) was required to pass this test compared with 45 percent boric acid of the coarser intermediate grind.

Polybor, which is chemically similar to borax, failed the divided box test over the range of 20 to 40 percent chemical in the mix (see figure 10). It is not surprising that the polybor failed the divided box test, since it contains sodium. It is surprising that at the 30 percent level one of two polybor mixtures passed the recessed light fixture test. For ease of comparison, some related information from reference [17], is summarized in table 4, and the test data for laboratory insulations are summarized in table 5 .

\subsection{Smolder Property Tests}

The three tests which are being investigated as candidates to provide heat release rate parameters were partially evaluated in terms of ease of use. These tests are the Bowes and Townshend [5] hot plate test, the TGA [8], and the adiabatic furnace $[9,10]$.

For untreated ground paper, a set of runs on the hot plate test 10 gave a value of $31700 \mathrm{cal} / \mathrm{mole}$ for the activation energy and $3.2 \mathrm{x} 10^{10}$
$\mathrm{ca} / \mathrm{sec} \cdot \mathrm{cm}^{3}$ for the Arrhenius pre-exponential factor. A set of runs for a similar material on a TGA apparatus gave a value of $54000 \mathrm{cal} / \mathrm{mole}$ for the activation energy using Flynn's method [18]. Although both these values are within the range of values for cellulosic materials $[9,19]$, the TGA value seems high. One cause for this value would be if the sample were overly compacted in the sample holder. In this situation the observed reaction would be that for a higher rate reaction than the one of interest [20], hence the need for standardizing the TGA test procedure for the particular material under test. The reduced data from a hot plate test series are shown in figure 11 .

For the untreated ground paper the adiabatic furnace gave a value of $26400 \mathrm{cal} / \mathrm{mole}$ for the activation energy and $1.65 \times 10^{8} \mathrm{cal} / \mathrm{sec} \cdot \mathrm{cm}^{3}$ for the pre-exponential factor. A test on a treated ground paper with 30 percent impalpable boric acid gave a value of $40400 \mathrm{cal} / \mathrm{mole}$ for the activation energy and $5.47 \times 10^{8} \mathrm{cal} / \mathrm{sec} \cdot \mathrm{cm}^{3}$ for the pre-exponential factor. The reduced data from an adiabatic furnace test series are shown in figure 12 .

The particular adiabatic furnace that was used for these tests was built in the 1950's and the data are reduced manually from a time temperature strip chart. During the course of the data reduction it was noted that the value of the activation energy was not very sensitive to small errors in picking the data off the chart, but the value of the pre-exponential factor was sensitive to these small errors; that is, a small change in the slope of $\mathrm{dT} / \mathrm{dt}$ vs $1 / \mathrm{T}$ produces a large change in the intercept (the pre-exponential factor). This sensitivity is typical of phenomena that are modeled by exponential functions. 
The advantages of the adiabatic furnace are that a fairly large sample is tested compared with thermal analyses, compacting the sample to the applied density improves the test performance, the test is easy to run, the data reduction is simple and unlike the hot plate test, a single test gives the required thermal parameters.

\section{DISCUSSION}

Three practical tests for evaluating the smoldering potential of loose fill cellulosic insulation were used in this study. The cigarette smoldering test indicated whether a smoldering wave could be generated by a small moving high temperature source, specifically a cigarette. The recessed light fixture test indicates whether a smoldering wave can be initiated in insulation covering an extended surface at high temperature, namely a recessed light fixture with an oversize bulb. The divided box test indicated whether a plane smoldering wave can propagate horizontally through the material once it is initiated. These three tests have been mentioned in order of increasing severity.

Three additional tests that would provide material properties, i.e., activation energy and pre-exponential factor, were examined. These are the Bowes and Townshend hot plate test, conventional thermal analyses, and the adiabatic furnace. The hot plate test appears to be cumbersome and tedious to run, and requires several tests to determine the smoldering temperature for a given thickness of insulation; thermal analyses require skilled people and standardization of the test procedure, and use a very small sample usually only a few milligrams in weight. The adiabatic furnace appears to be the easiest and most satisfactory. The methods for calculating the activation energy and the pre-exponential factor are mathematically similar for both the hot plate [5] and the adiabatic furnace [10]. Therefore, in principle, it should be possible to use the data from one of these tests to calculate the data derived from the other. Following this idea, a method was developed to generate from the adiabatic furnace data a relationship between thickness of layer of insulation and equivalent hot plate temperature. The method is described in appendix $B$ at the back of this report.

The results of this analysis are compared with the results of the hot plate tests in figure 13 and show better correlation for thicker layers than for thinner layers. This is not surprising as the adiabatic furnace ignition conditions approach those of the hot plate more closely for thick layers. Fortunately in most practical applications, such as attic floors and exterior walls, the thickness of the layers of insulation would be in the range of 10 to $25 \mathrm{~cm}$ or larger, and for this range of thicknesses the ignition parameters derived from the adiabatic furnace would be satisfactory.

While a number of commercial insulations have passed the cigarette ignition test, none has consistently passed the recessed light fixture test or the divided box test. The amount of intermediate grind boric acid that had to be added to untreated cellulosic insulation in order to 
pass the cigarette smoldering test was 7.5 percent, while 45 percent was needed to pass the recessed light fixture test and the divided box test. The addition of 10 percent borax to the insulation increased the amount of intermediate grind boric acid needed to pass the cigarette smoldering test to 20 percent. Since it was found that boric acid is approximately as effective in increasing the critical radiant flux as borax and that borax is a smolder promoter rather than a smolder inhibitor it would appear that boric acid alone would be more effective in reducing the overall combustion potential of loose fill cellulosic insulation.

Polybor which was obtained in a small particle size (70 percent less than 45 microns) was found to be effective in passing the recessed light fixture test at a concentration of 30 percent. However, it would not pass the divided box test in concentrations as high as 40 percent. Going to still smaller particle size the impalpable boric acid ( 80 percent less than 45 microns) passed the divided box test at a concentration of 35 percent. Thus the finer the grind and dispersion of the retardant the greater its effectiveness. The results with the polybor also support the contention that the divided box test for smoldering propagation is more severe than the recessed light fixture test for smoldering ignition.

Though this investigation concentrated on the smoldering phenomenon, the overall question of fire safety posed by significant amounts of insulation in residences should also be investigated. Such an investigation should include tests on both full size compartments and reduced scale compartments, as well as computer simulations of various scenarios.

\section{CONCLUSIONS}

be drawn:

Based on the results of this study, the following conclusions may

1. Commercial loose fill cellulosic insulations examined in this study were unable to pass the recessed light fixture test.

2. The divided box test is a good screening test and is conservative.

3. The fineness and dispersion of the fire-retardant chemical increases both the smolder resistance and flame resistance of loose fill cellulosic insulation.

4. Borax promoted the tendency to smolder and increased the concentration of boric acid required to inhibit smoldering.

5. Borax and boric acid appear to be equally effective in increasing the critical radiant flux, $1 . e .$, limiting the extent of surface flame spread.

6. The hot plate test is a slow and cumbersome method for deriving kinetic reaction data. 
7. The adiabatic furnace provided kinetic reaction data more easily than does the hot plate apparatus. Furthermore, from this test it is possible to derive a relationship between thickness of insulation and equivalent hot plate temperatures.

\section{RECOMMENDATIONS}

1. Continue work on developing a test method for characterizing the smoldering potential of insulations in terms of their effective kinetic reaction parameters.

2. Discontinue use of the hot plate apparatus for deriving kinetic reaction data.

3. Concurrent with recommendation $\|_{1} 1$ above, investigate the overal1 fire performance of insulation in residences using full size and reduced scale model compartments and computer simulation.

\section{ACKNOWLEDGMENTS}

Important help was provided by industry and government agencies on this project. In particular, I wish to acknowledge the assistance of George Andrews of Therma-Coustics Manufacturing, Inc., who provided a mixer/blower for preparing the cellulosic insulations, and to Robert W. Sprague of the U.S. Borax Research Corporation, who provided samples of impalpable ground boric acid and polybor chemicals, and unpublished information on the chemistry of boron compounds. Other industry sources offered insulation, chemicals, and information on processing. Nestor B. Knoepfler of the U.S. Department of Agriculture provided information on their work on fire retardants and samples of vapor applied boric acid cellulosic insulations. John Rockett and Sanford Davis of the CFR suggested this version of the divided box test. Tom Prather, Lee Dunlap, and Dennis Sullivan performed most of the tests on this project. Roy Lindauer designed and built the frame to support the blower/mixer. Joseph Loftus assisted in running the adiabatic furnace. Particular thanks to William J. Parker and Dan Gross for their review and suggestions during the preparation of this report.

\section{REFERENCES}

[1] Standard Test Method for Surface Flaming Characteristics of Building Materials, ASTM E84-79. American Society for Testing and Materials, Philadelphia, Pa. (1979).

[2] Federal Specification HH-I-515D Insulation Therma1 (Loose Fill for Pneumatic or Poured Application) Cellulosic or Wood Fiber, General Services Administration, Washington, D.C. (June 1978). 
[3] Private communication from the Oklahoma City Fire Department, 1970.

[4] Rogers, F., Ohlemiller, T. J., and Summerfield, M., Studies of the Smoldering Combustion of Flexible Polyurethane Cushioning Materials, Journal of Fire and Flammability, Vo1. 9, pp. 5-13 (January 1978).

[5] Bowes, P. C. and Townshend, S. E., Ignition of Combustible Dusts on Hot Surfaces, British Journal of App1ied Physics, Vo1. 13, pp. 105114, England (1957).

[6] Thomas, P. H. and Bowes, P. C., Thermal Ignition in a Slab with One Face at a Constant High Temperature, Transactions of the Faraday Society, Vo1. 57, pp. 2007-2017, London, England (1961).

[7] Schaffer, E. L., On Smolder Initiation in Cellulosics Under Prolonged Low Level Heating, Forest Products Laboratory, Madison, Wisconsin (1979), in preparation.

[8] Jellinek, H. H. G., Aspects of Degradation and Stabilization of Polymers, Elsevier Scientific Publishing Co., New York, N.Y. (1978).

[9] Gross, D. and Robertson, A. F., Self Ignition Temperatures of Materials from Kinetic Reaction Data, J. Res. Nat. Bur. Stand. (U.S.), Vo1. 61, No. 5, pp. 413-417, (1958).

[10] Raskin, W. H. and Robertson, A. F., An Adlabatic Apparatus for the Study of Self-Heating of Poorly Conducting Materials, The Review of Scientific Instruments, Vo1. 25, No. 6, pp. 540-544 (1944).

[11] Ohlemiller, T., private communication (1979).

[12] Carslaw, H. S. and Jaeger, J. G., Conduction of Heat in Solids, Oxford University Press, London, England (1959).

[13] Knoepfler, N. B., Madacsi, J. P. and Neumeyer, J. P., Permanence of Boron Containing Treatment for Cotton Batting Products That Meet the Mattress Flammability Standard FF 4-72, Journal of Flame and Flammability/Fire Retardant Chemistry, Vo1. 2, p. 65 (May 1975).

[14] Day, M. and Wiles, D. M., Combustibility of Loose Fill Cellulose Insulation: The Role of Borax and Boric Acid, Journal of Consumer Product Flammability, Vo1. 5, pp. 113-122 (1978).

[15] Walker, P. L., Chemistry and Physics of Carbon, London, England (1968).

[16] Hawley, G. G., Condensed Chemica1 Dictionary, 8th Edition, Van Nostrand-Reinhold Co., New York, N.Y. (1972). 
[17] Gross, D., A Preliminary Study of the Fire Safety of Thermal Insulation for Use in Attics or Enclosed Spaces in Residential Housing, Nat. Bur. Stand. (U.S.), NBSIR 78-1497 (1978).

[18] Flynn, J. H. and Wall, L. A., A Quick Direct Method for the Determination of Activation Energy From Thermogravimetric Data, Polymer Letters, Vo1. 4, pp. 323-328 (1966).

[19] Min, K., Dynamics of Pyrolysis of Cellulosic Materials. Presented at the Joint Combustion Institute Meeting, San Antonio, Texas (1975).

[20] Menis, 0., Status of Thermal Analysis, Nat. Bur. Stand. (U.S.), Spec. Pub1. 338 (1970).

[21] Turner, J. S., Buoyancy Effects in Fluids, Cambridge University Press, London, England (1973).

[22] Kreith, F., Principles of Heat Transfer, 2nd Edition, International Textbook Co., Scranton, Pa. (1965). 
Table 1. Results of smolder tests HH-I-515D

\begin{tabular}{ccccccc}
\hline $\begin{array}{c}\text { Batch } \\
\text { no. }\end{array}$ & $\begin{array}{c}\text { Density } \\
\text { pcf }\end{array}$ & $\begin{array}{c}\text { Concentration of chemical } \\
\text { Borax }\end{array}$ & $\begin{array}{c}\text { Boric acid } \\
\%\end{array}$ & $\begin{array}{c}\text { Total } \\
\%\end{array}$ & $\begin{array}{c}\text { Weight } \\
\text { loss } \\
\%\end{array}$ & Remarks \\
\hline 1 & 3.0 & 10 & 10 & 20 & 56 & fail \\
2 & 3.0 & 10 & 15 & 25 & 54 & fail \\
3 & 3.0 & 10 & 20 & 30 & 0 & pass \\
4 & 3.0 & 10 & 25 & 35 & 0 & pass \\
5 & 3.0 & 0 & 10 & 10 & 0 & pass \\
6 & 3.0 & 0 & 7.5 & 7.5 & 0 & pass \\
7 & 3.0 & 0 & 5 & 5 & 0 & fail \\
\hline
\end{tabular}

${ }^{1}$ Percent chemical as a fraction of the overall weight of the mixture 
Table 2. Commercial Insulation - recessed light fixture test

\begin{tabular}{|c|c|c|}
\hline Materlal & $\begin{array}{c}\text { Density } \\
\text { pef }\end{array}$ & Result \\
\hline$c-1$ & 2.9 & $\mathbf{F}$ \\
\hline$c-2$ & 2.2 & $\mathbf{F}$ \\
\hline$c-3$ & 2.5 & F \\
\hline$c-6$ & 2.3 & $\mathbf{F}$ \\
\hline$c-8$ & 2.3 & $\mathbf{F}$ \\
\hline c-9 & 3.3 & $\mathbf{F}$ \\
\hline$c-10$ & 2.0 & $\mathbf{F}$ \\
\hline$c-11$ & 3.1 & $\mathbf{F}$ \\
\hline$c-15^{1 /}$ & 2.2 & $\mathbf{P}$ \\
\hline & 2.3 & $\mathbf{F}$ \\
\hline & 3.0 & $\mathbf{F}$ \\
\hline$c-16^{2 /}$ & 3.0 & $\mathbf{F}$ \\
\hline $\mathbf{P}$ & 3.7 & $\mathbf{F}$ \\
\hline $\mathbf{Q}$ & 3.0 & $\mathbf{F}$ \\
\hline
\end{tabular}

I/ Same material different supplier

2/ Wood fiber 


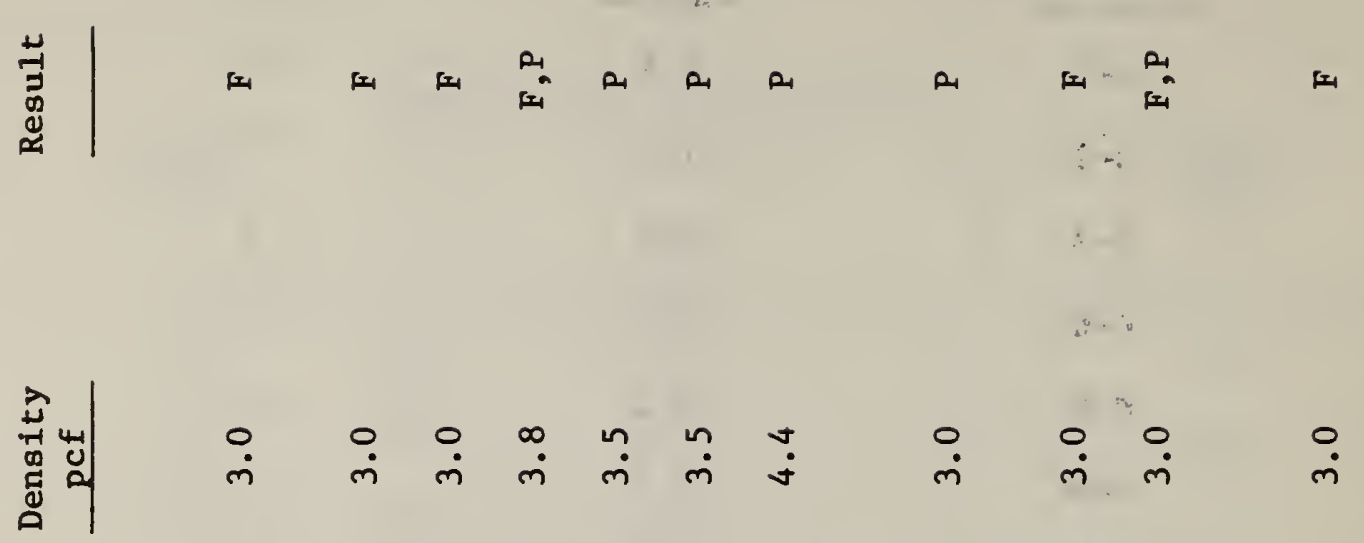

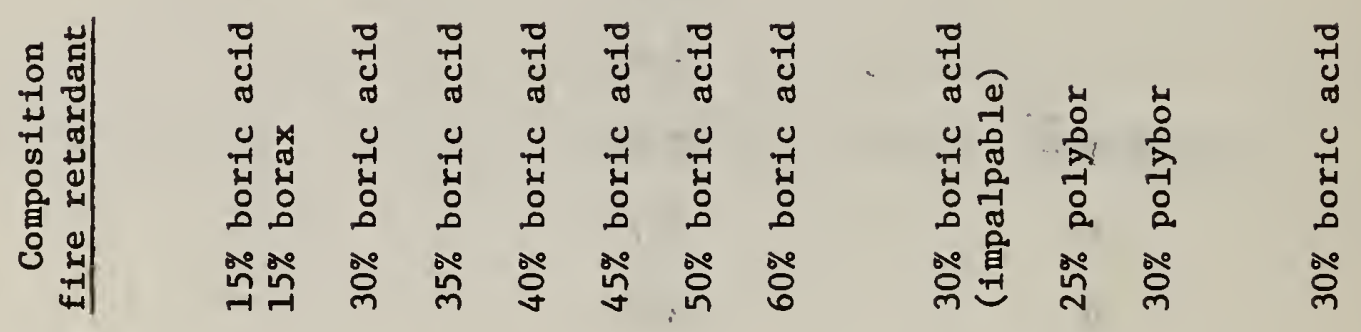

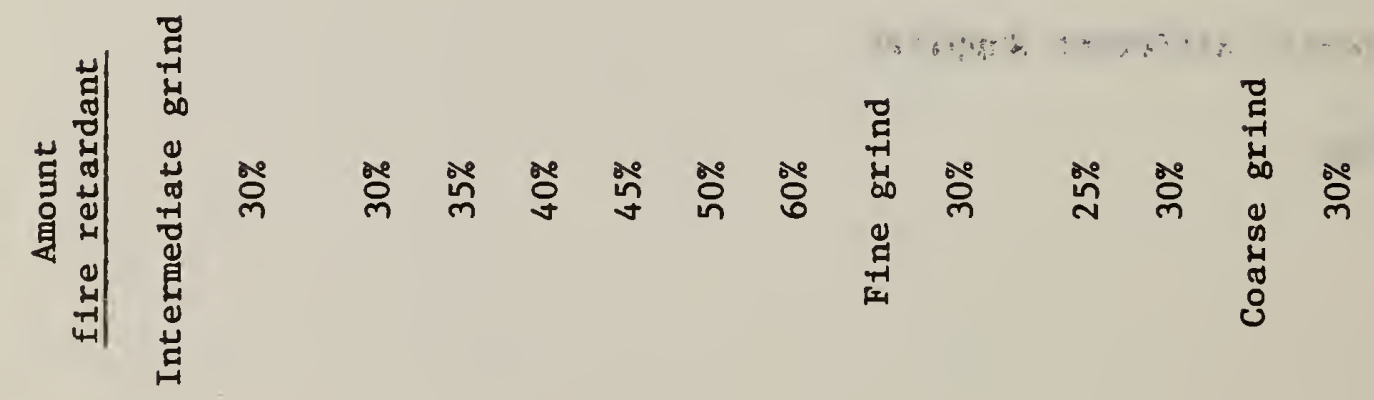




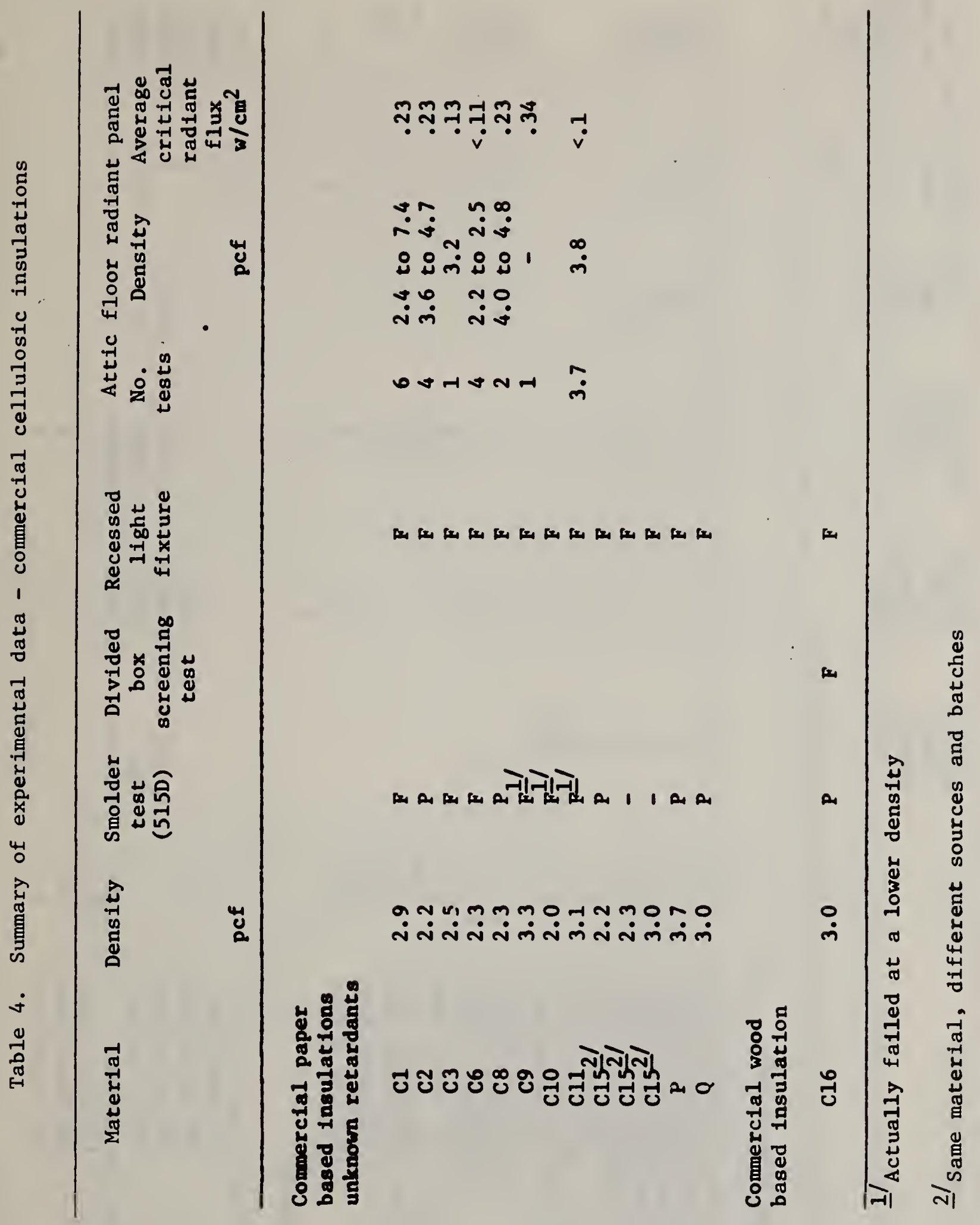




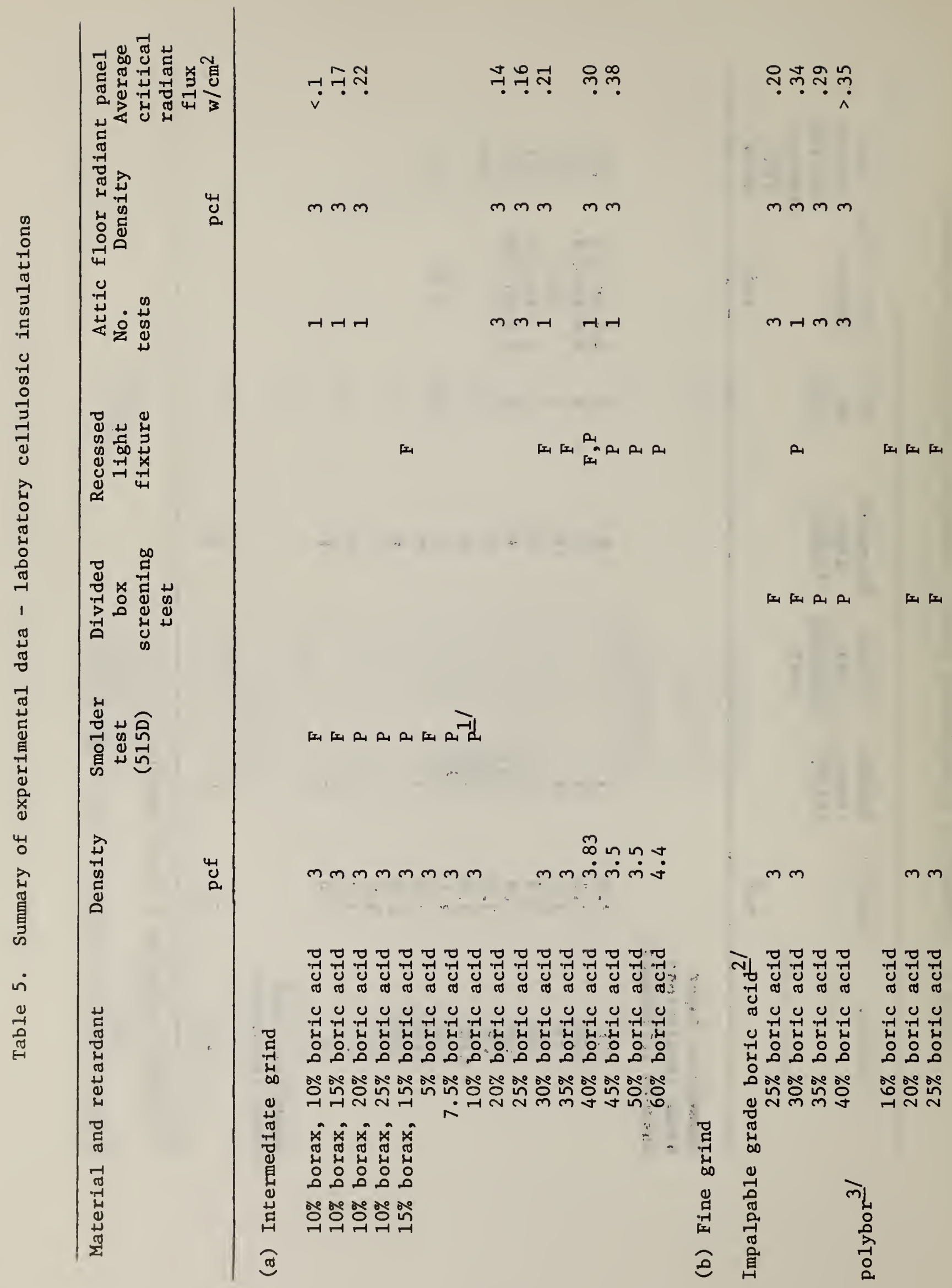




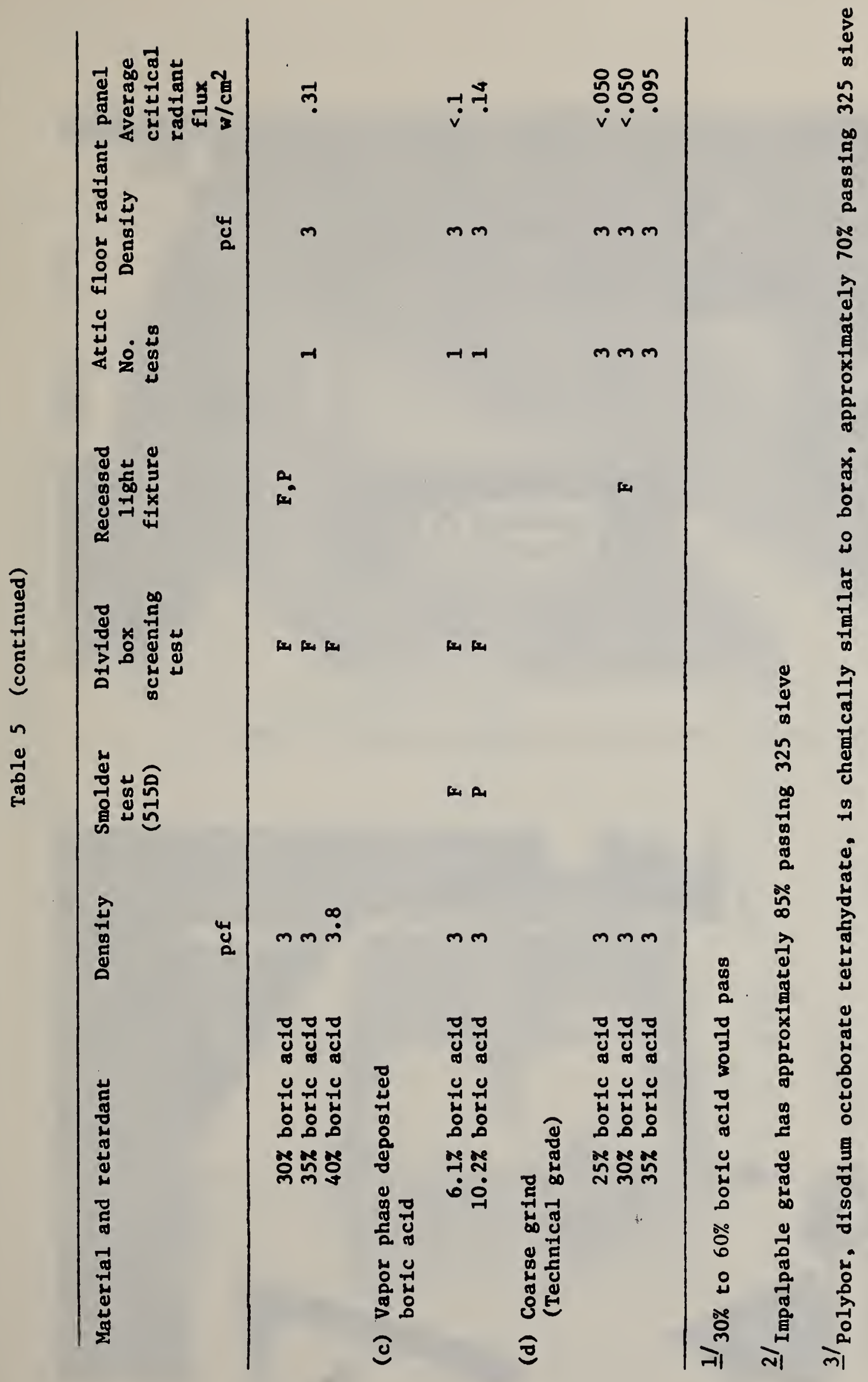




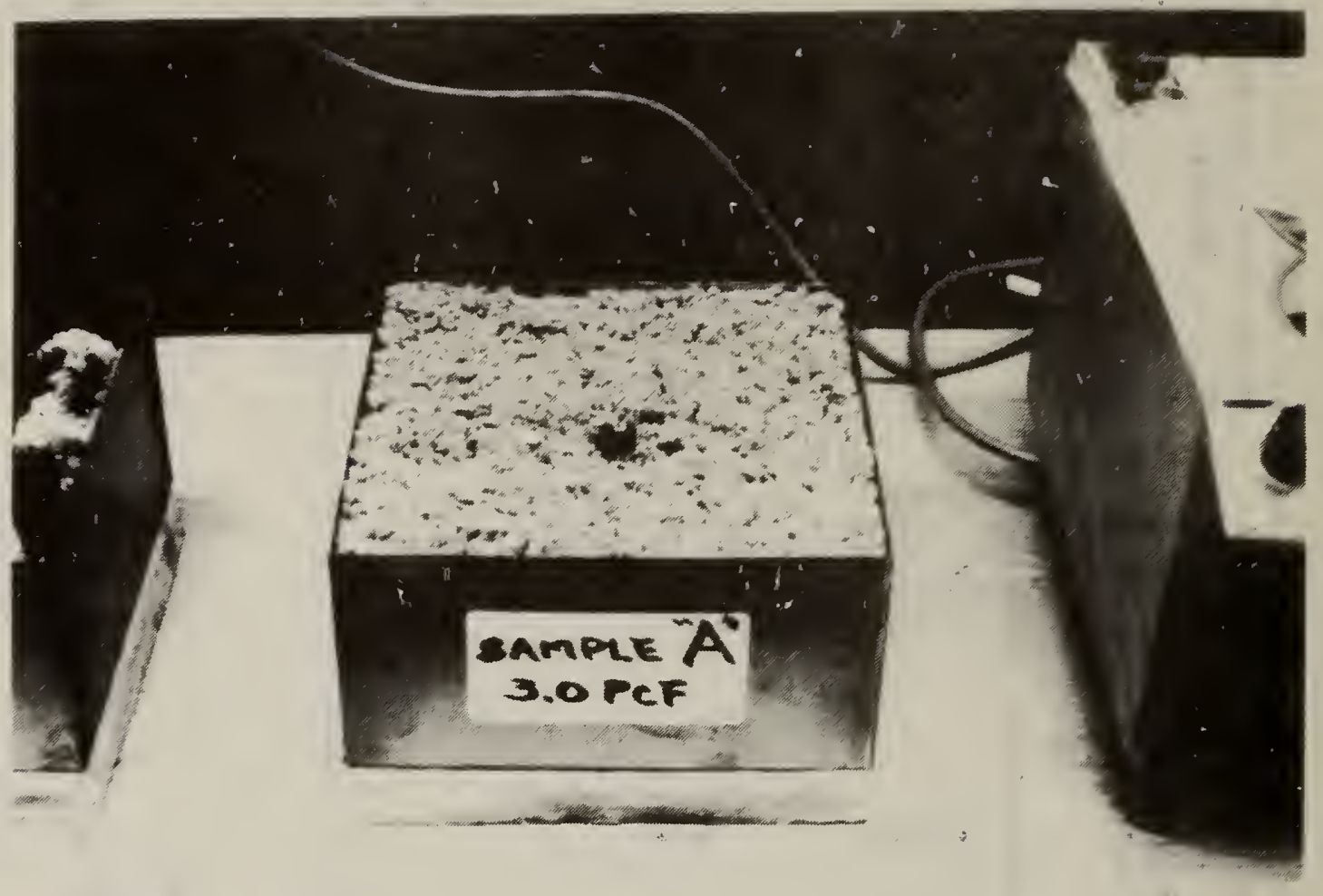

Figure 1. Cigarette smoldering test

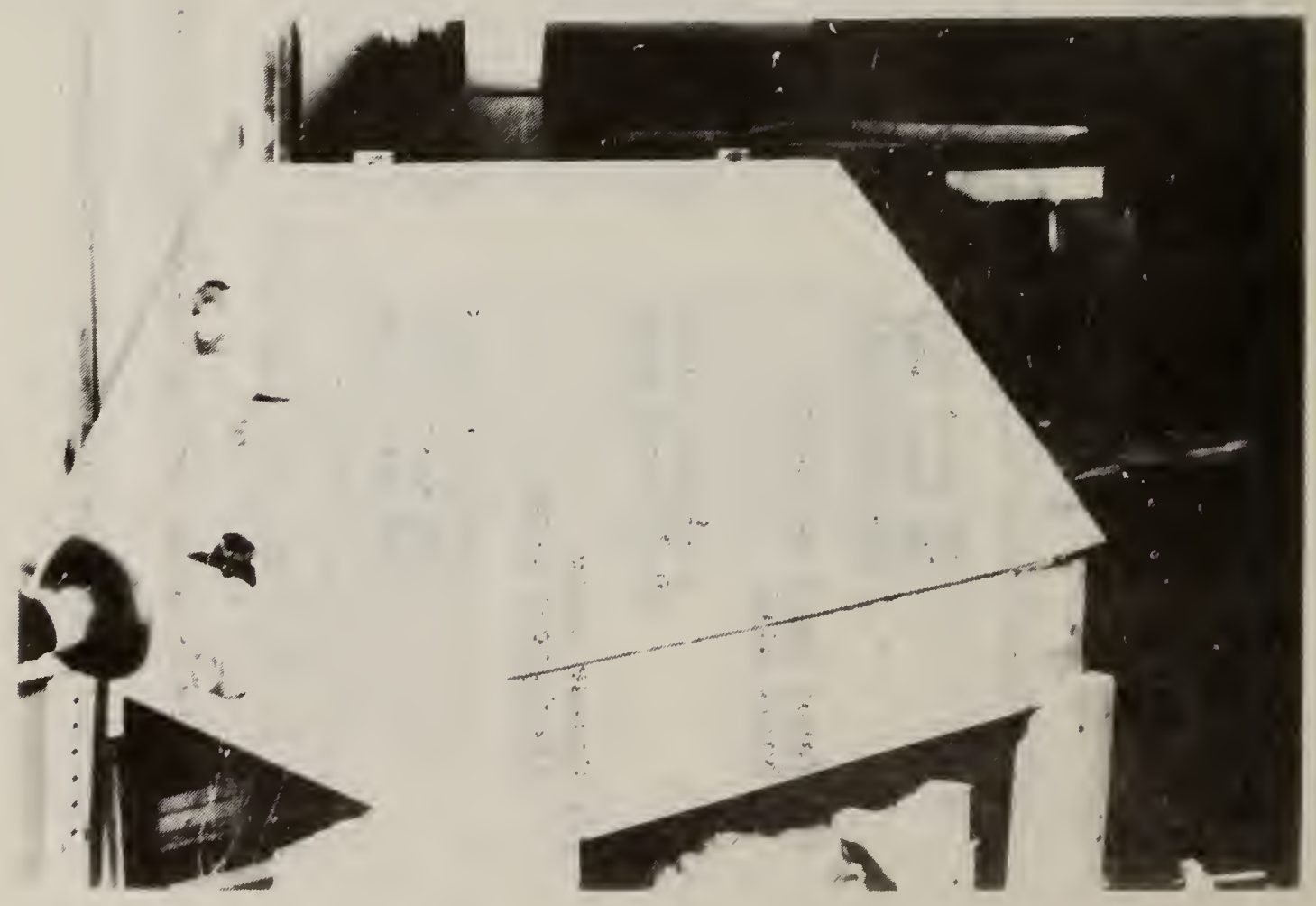

Figure 2. Recessed light fixture test exterior view 


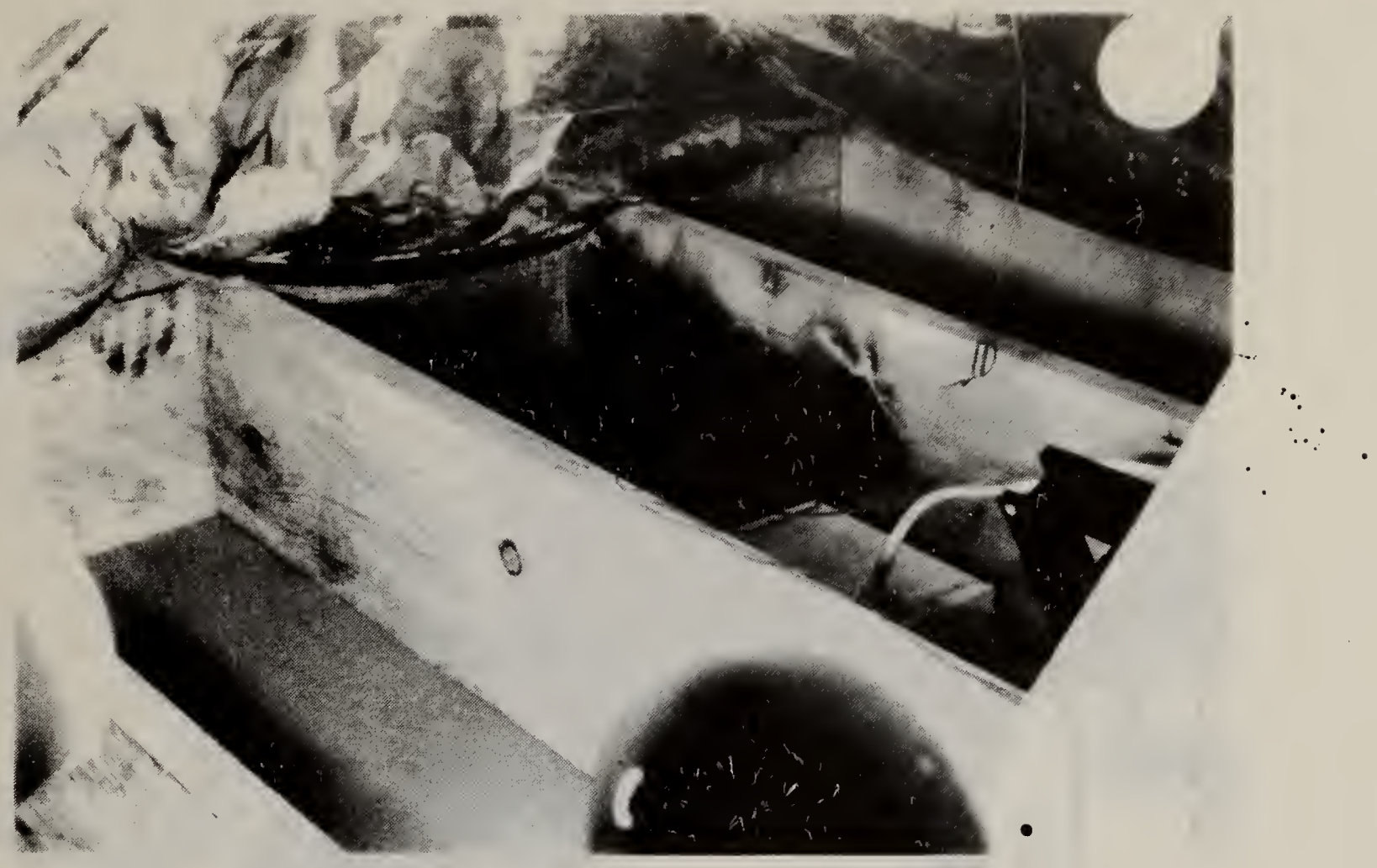

Figure 3. Recessed light fixture test interior view

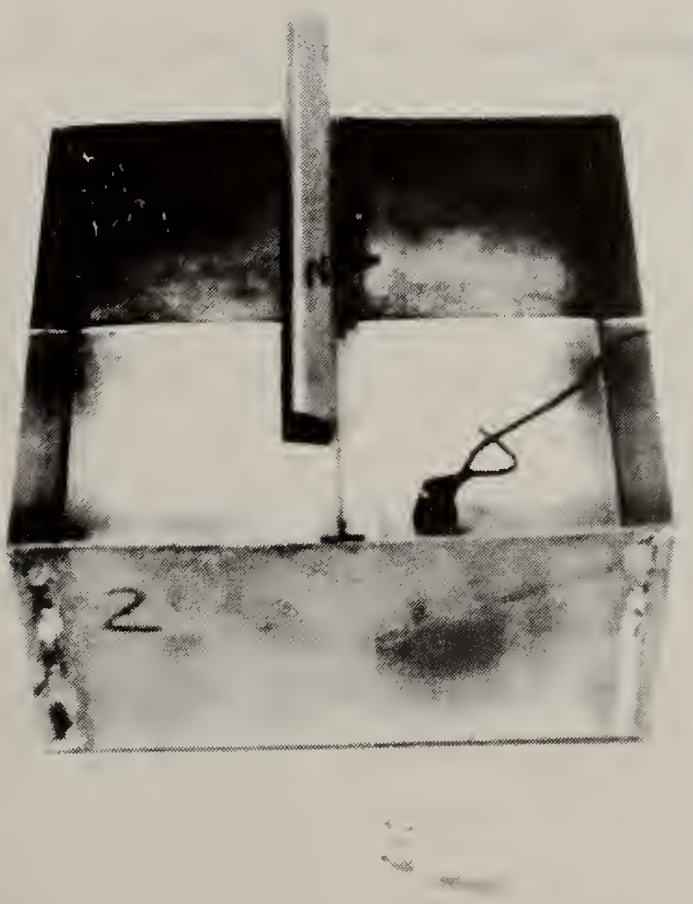

Figure 4. Divided box test 


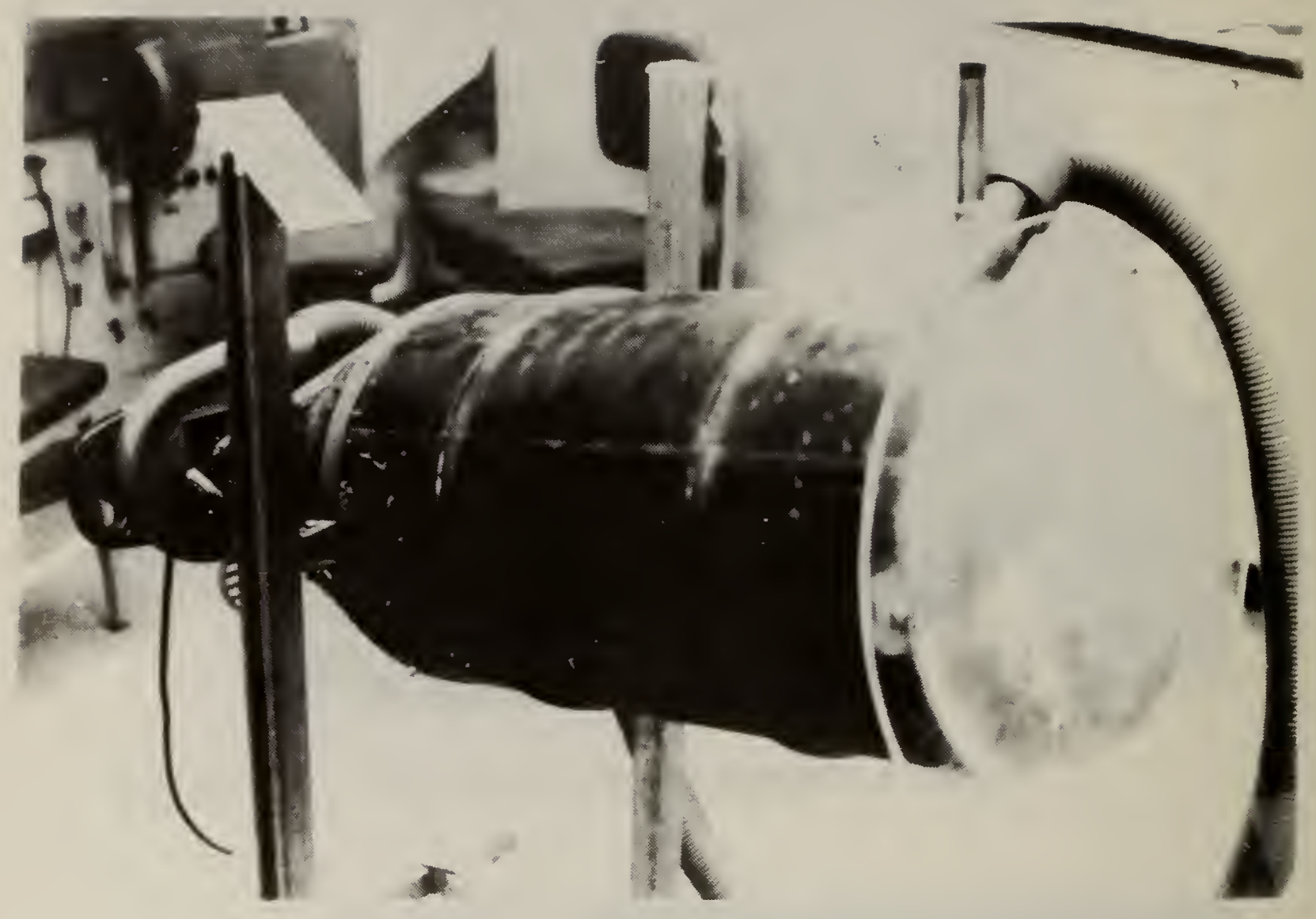

Figure 5. Blower mixer for preparing laboratory insulations 

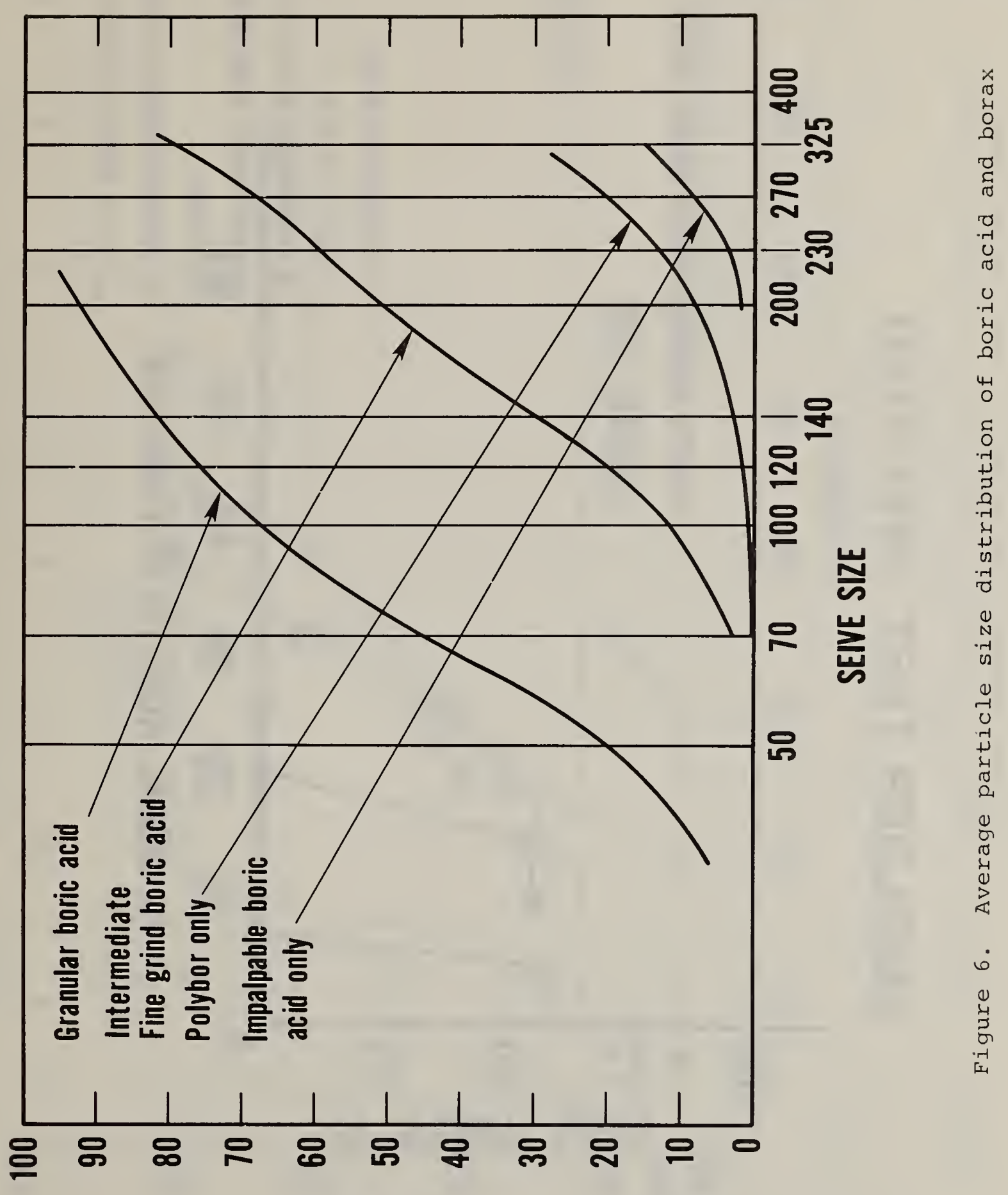

03NIY13Y \% 


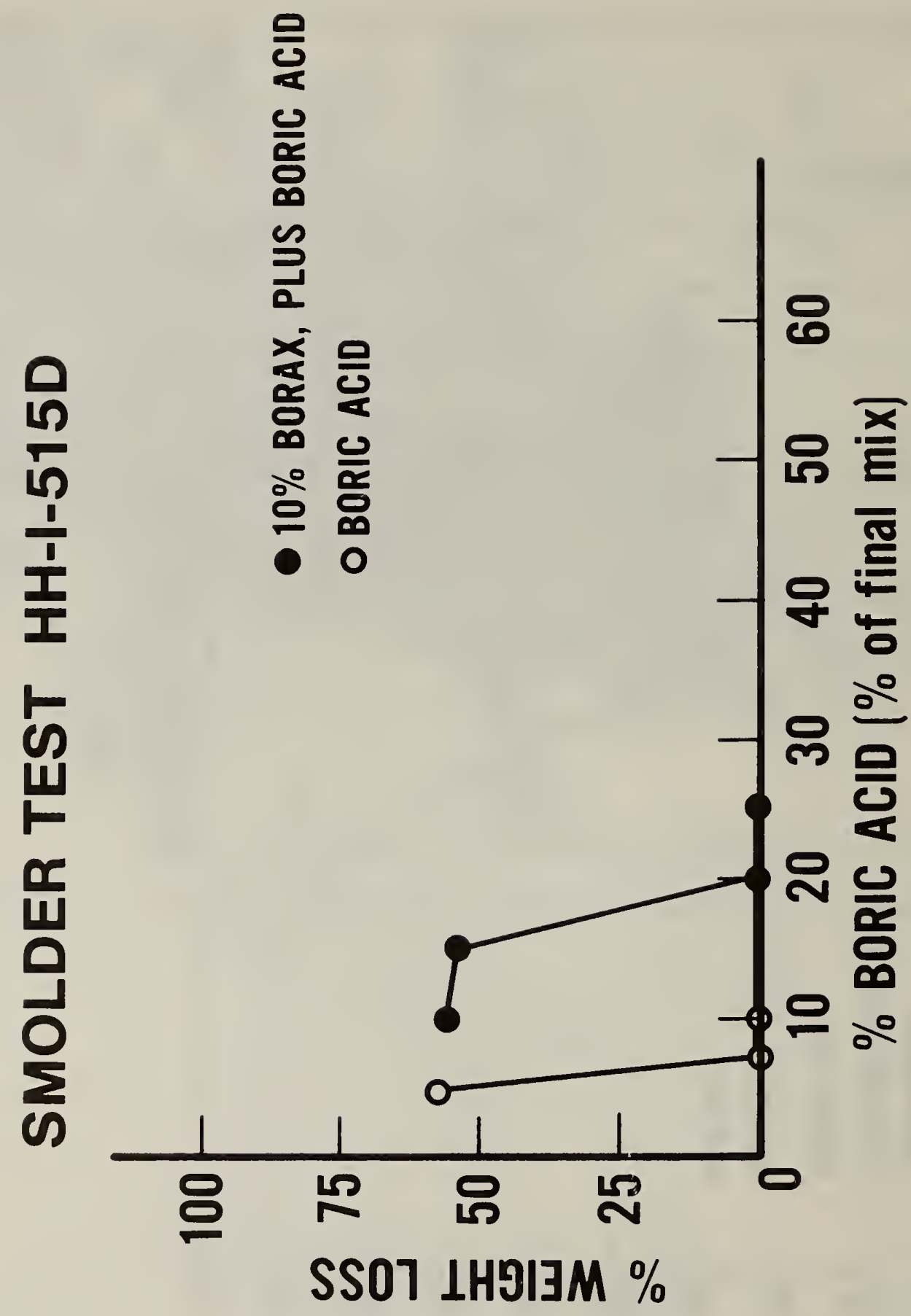




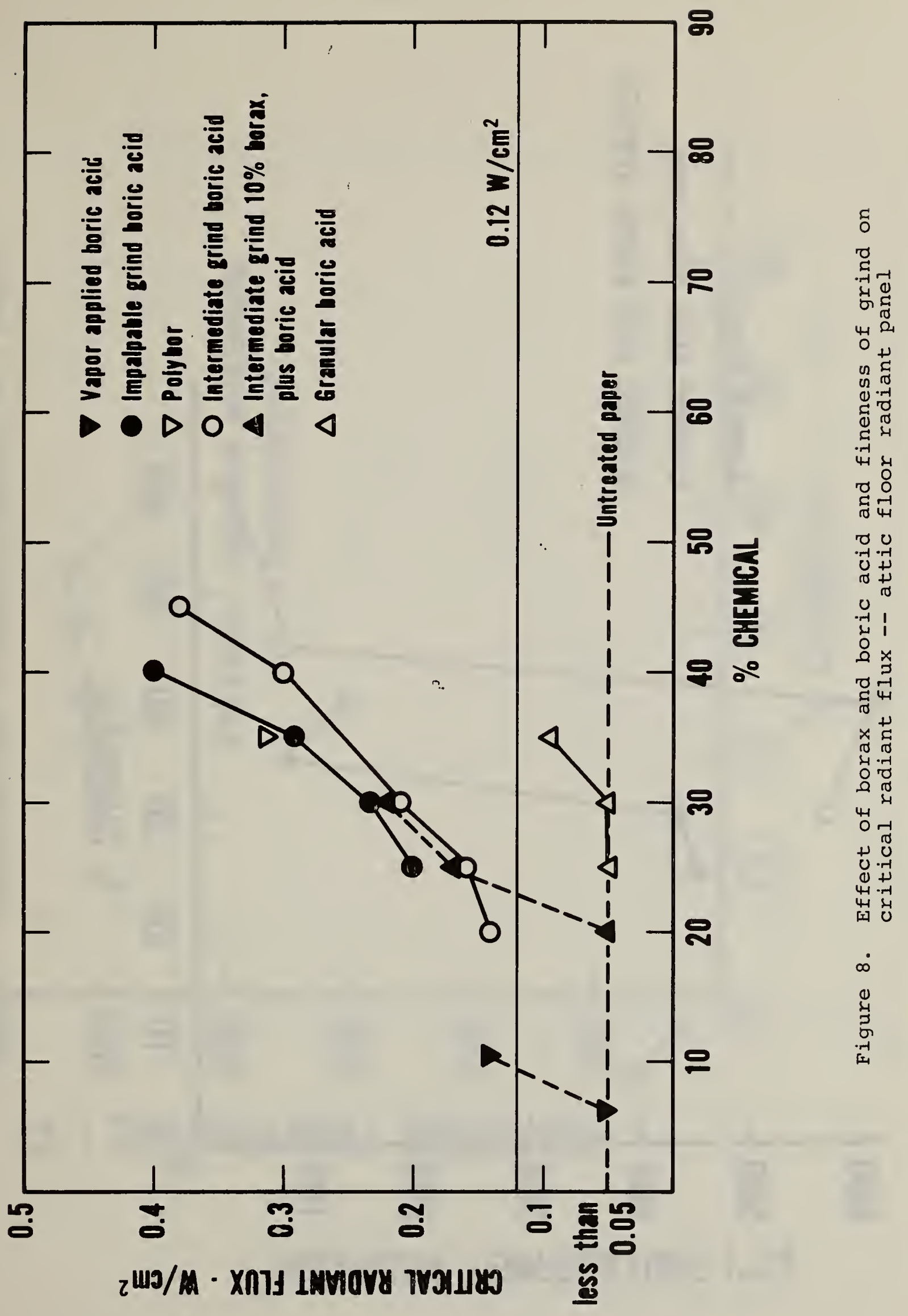




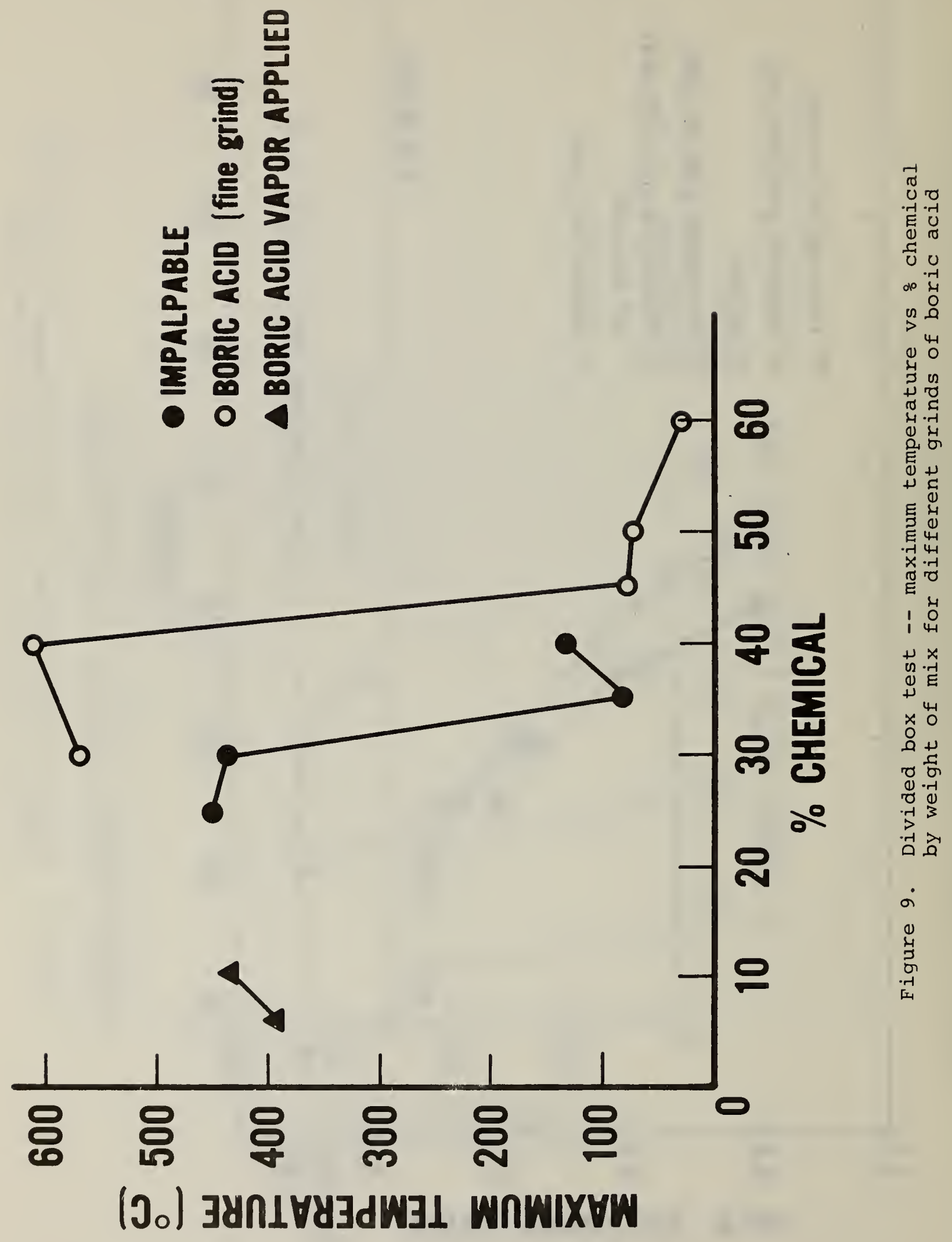




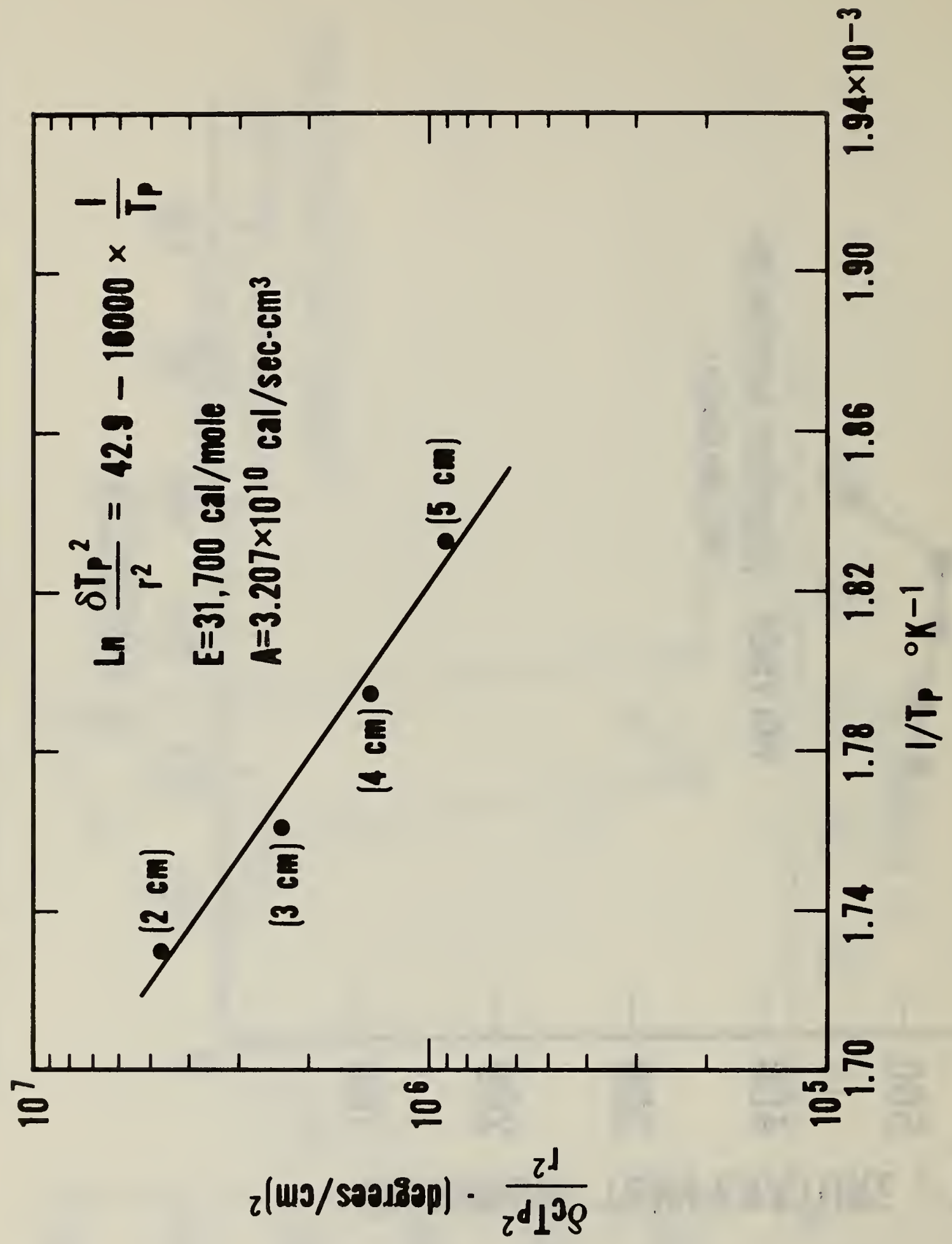

O 


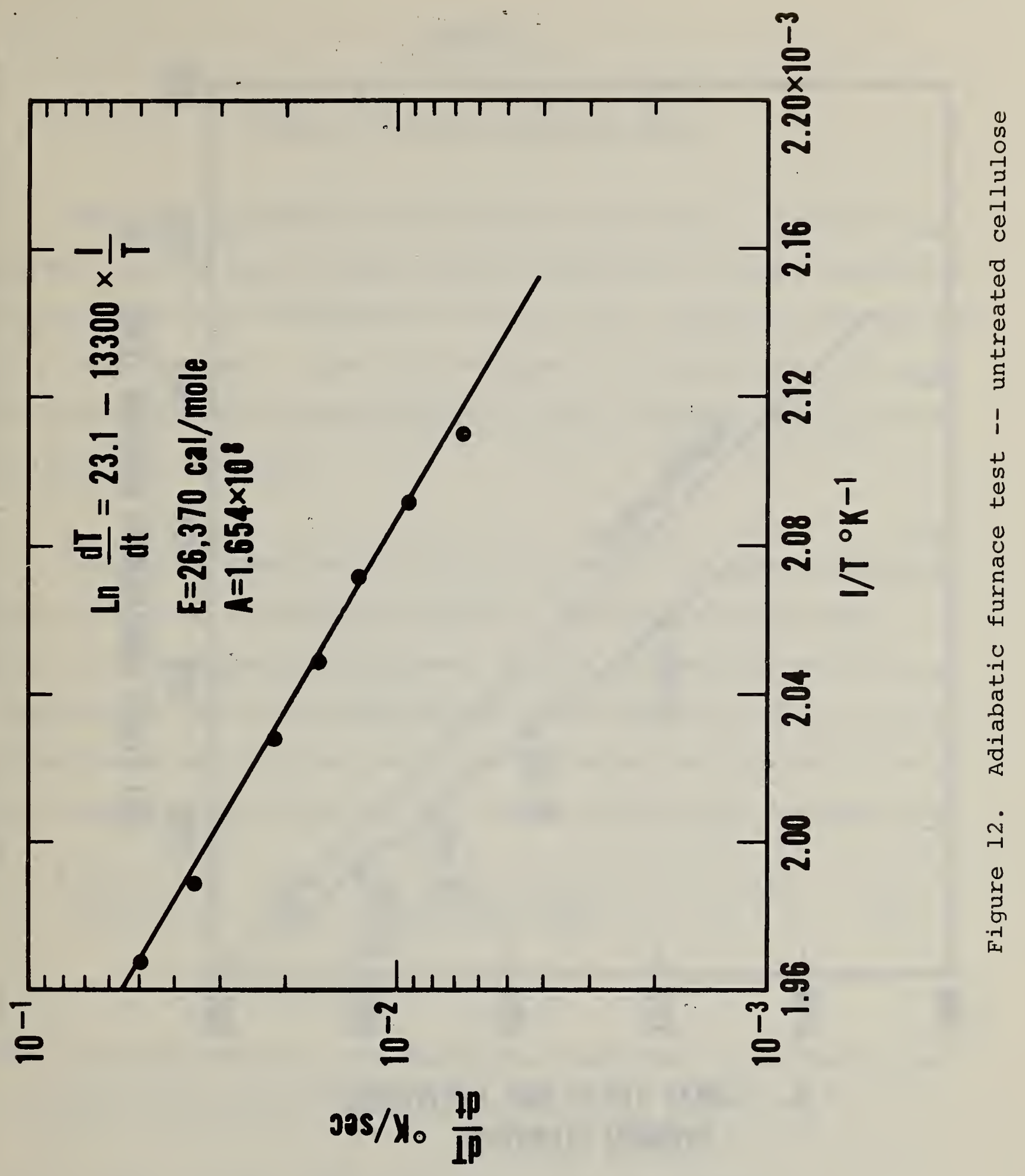




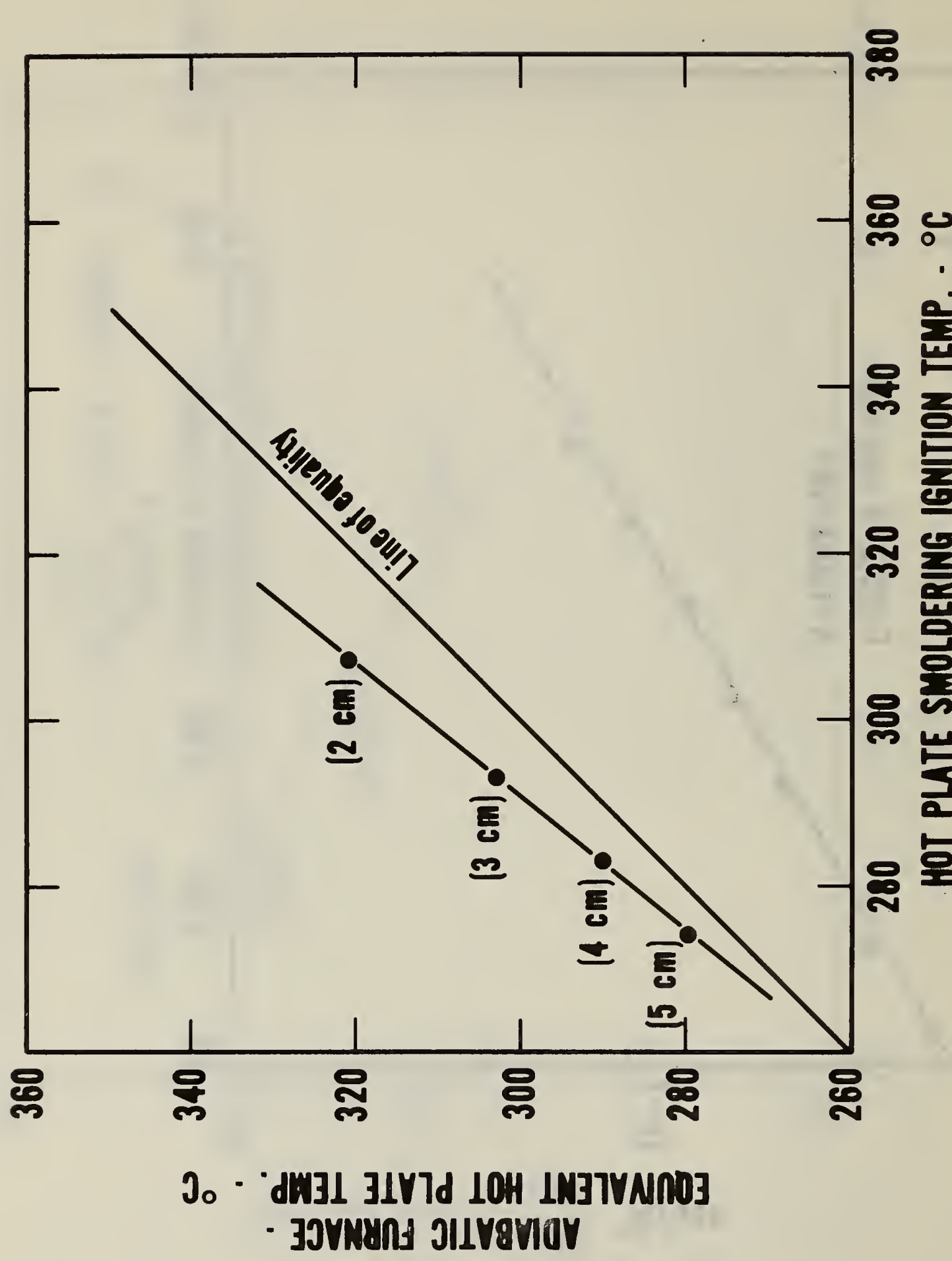




\section{APPENDIX A}

CRITERIA FOR TIME OF SMOLDERING TESTS

Ohlemiller's criterion is that the time for the slope of temperature, $\mathrm{dT} / \mathrm{dx}$, at the hot plate to reach a nearly constant value or quasi steady state is the time that the smoldering test should be run. Ohlemiller calls this time the "relaxation time". Since this time appears to be significantly less than that observed in the recessed light fixture test, a detailed analysis of this criterion was undertaken.

In analyzing Ohlemiller's approach to relaxation time, the calculations were redone using dimensionless parameters. These were the Biot number $\left(B_{i}=L H / K\right)$ or dimensionless thickness, the Fourier number $\left(F_{0}=\alpha t / L^{2}\right)$ or dimensionless time, and the dimensionless temperature $\left(T-T_{0}\right) /\left(T_{p}-T_{0}\right)$. The Ohlemiller criterion for the time to run a smoldering test is based on Carslaw and Jaeger [12] case VI page 126, which may be written in the following form:

$\bar{T}=\frac{1+B_{i}(1-\bar{x})}{1+B_{i}}-\sum_{n=1}^{\infty} \frac{2\left(B_{n}^{2}+B_{i}^{2}\right) \sin \left(B_{n} \cdot \bar{x}\right)}{B_{n}\left(B_{i}+B_{i}^{2}+B_{n}^{2}\right)} \cdot e^{-B_{n}^{2} F}$

the dimensionless slope of the dimensionless temperature versus dimensionless distance is then given by

$\frac{d \bar{T}}{d \bar{x}}=-\frac{B_{i} \bar{x}}{1+B_{i}}-\sum_{n=1}^{\infty} \frac{2\left(B_{n}^{2}+B_{i}^{2}\right) \cos \left(B_{n} \cdot \bar{x}\right) \cdot B_{n}}{B_{n}\left(B_{i}+B_{i}^{2}+B_{n}^{2}\right)} \cdot e^{-B_{n}^{2} F}$ 
The slope at the hot plate, $\bar{x}=0$, is of primary interest. Thomas and Bowes [6] found that in their mathematical model for smoldering in a layer heated on one side the maximum temperature occurs at a short distance away from the hot plate, at approximately $0.012 \leq \bar{x} \leq 0.052$. In the calculation for the slope, equation (2) above, the differences in the time to reach quasi steady state at these locations were negligibly different from those at the hot plate.

The plot of the slope of the temperature at the hot plate (in dimensionless terms), shown in figure A-1, indicates that for relatively thick layers of insulation, with $B_{i}$ greater than about 10 , Ohlemiller's criterion is satisfied. That is the slope of the temperature at the hot plate becomes almost constant after $F_{0} \geq 0.5$, approximately. For a relatively thin layer, $B_{i}$ about equal to 1 , the slope becomes almost constant only at later times, that is $F_{0} \geq 0.9$, approximately.

In order to determine the range of actual thicknesses of insulation corresponding to the range of Biot numbers, it was necessary to determine a surface coefficient of heat transfer that is independent of the plan size of the insulation layer. One such relation, given by Turner [21] is

$$
\mathrm{N}_{\mathrm{u}}=0.17\left[\mathrm{P}_{\mathrm{r}} \cdot \mathrm{R}_{\mathrm{a}}\right] 1 / 3
$$

after writing out the terms, noting that for air $\mathrm{P}_{\mathrm{r}}=0.7$ over a large range of temperatures [22] we have

$$
H_{c}=0.17 \quad K_{a}\left[\frac{0.7 g \Delta T}{T_{0} \alpha_{a} \nu}\right]^{1 / 3}
$$


where the material properties refer to those for air, and $T_{0}$ is in absolute temperature. Using the properties for air tabulated by Kreith [22] we have

$$
\begin{aligned}
\mathrm{H}_{\mathrm{c}}= & 4.26 \times 10^{-5} \Delta \mathrm{T}^{1 / 3} \mathrm{cal} /\left(\mathrm{cm}^{2} \cdot \mathrm{s} \cdot{ }^{\circ} \mathrm{C}\right) \\
& \text { or } 1.73 \Delta \mathrm{T}^{1 / 3} \mathrm{~W} /\left(\mathrm{m}^{2} \cdot{ }^{\circ} \mathrm{K}\right)
\end{aligned}
$$

The heat losses from the top surface of the layer of insulation should also include a term for radiation heat losses. This term as given by Carslaw and Jaeger [12] is

$$
\begin{aligned}
H_{R} & =\sigma \varepsilon \frac{\left[T_{s}^{4}-T_{0}^{4}\right]}{T_{s}-T_{0}} \text { with } \varepsilon=0.8 \text { we have } \\
& =1.096 \times 10^{-12} \frac{\left[T_{s}^{4}-T_{0}^{4}\right]}{T_{s}-T_{0}} \mathrm{cal} / \mathrm{cm}^{2} \cdot \mathrm{s} \cdot{ }^{\circ} \mathrm{C}
\end{aligned}
$$

and

$$
\mathrm{H}_{\mathrm{T}}=\mathrm{H}_{\mathrm{c}}+\mathrm{H}_{\mathrm{R}}
$$

The results are shown in figure $\mathrm{A}-2$.

Equations (4) and (5) show that $\mathrm{H}_{\mathrm{T}}$ is a function of the ambient temperature and the surface temperature. Thus in order to determine the correct Biot number, or conversely the thickness corresponding to a particular Biot number, the dimensionless surface temperature was determined for a range of Biot numbers and Fourier numbers. This is shown in figure $\mathrm{A}-3$. 
For $\mathrm{T}_{\mathrm{s}}$ of $30^{\circ} \mathrm{C}, \mathrm{H}_{\mathrm{T}}=2.078 \times 10^{-4}$, and for a thickness of insulation of $10 \mathrm{~cm}$, the Biot number is 16.7. Since this is greater than 10, and referring to figure 11 we can assume that for most hot plate type smoldering tests, the layer of insulation is thick and Ohlemiller's criterion is satisfied. 


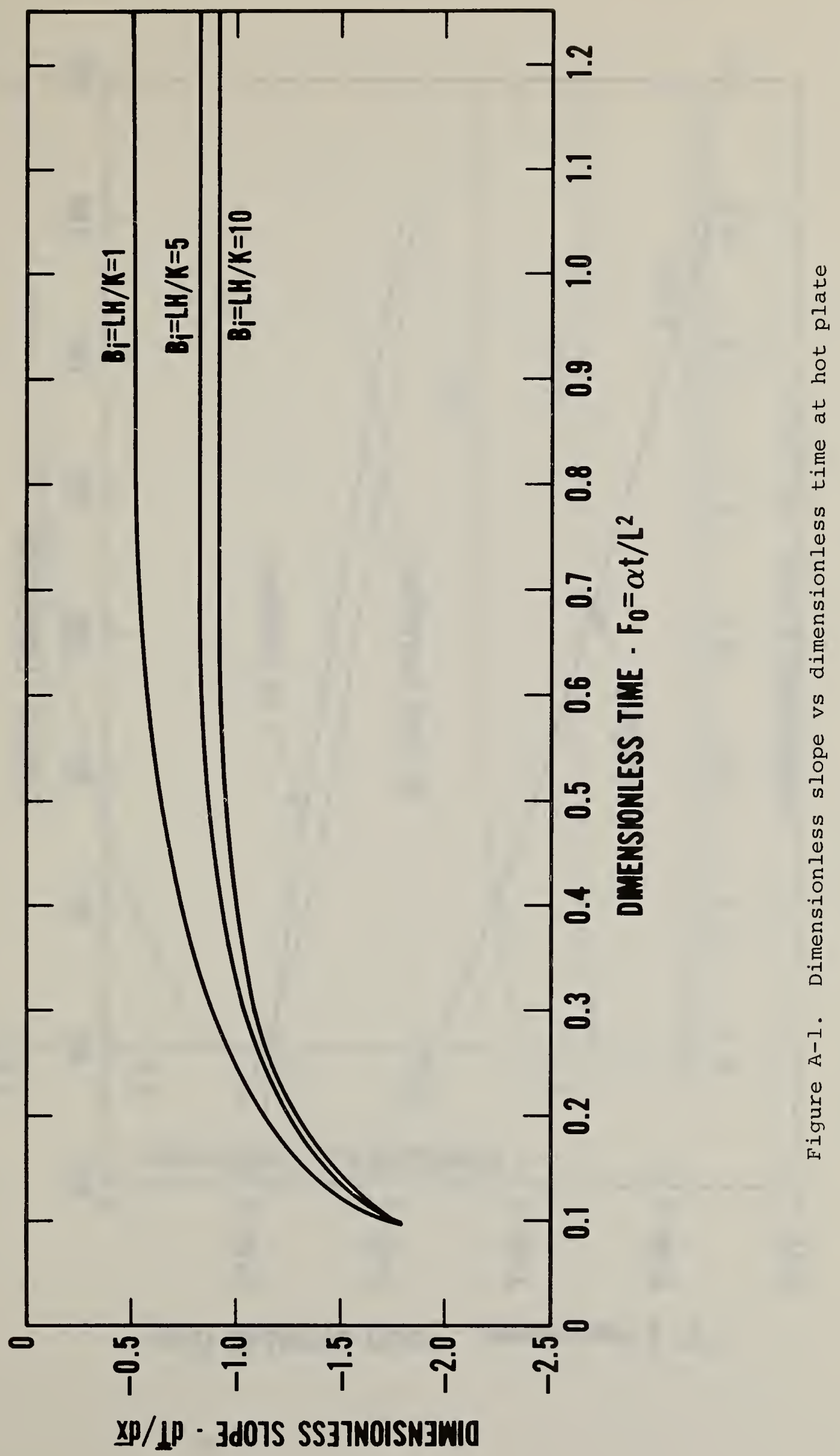




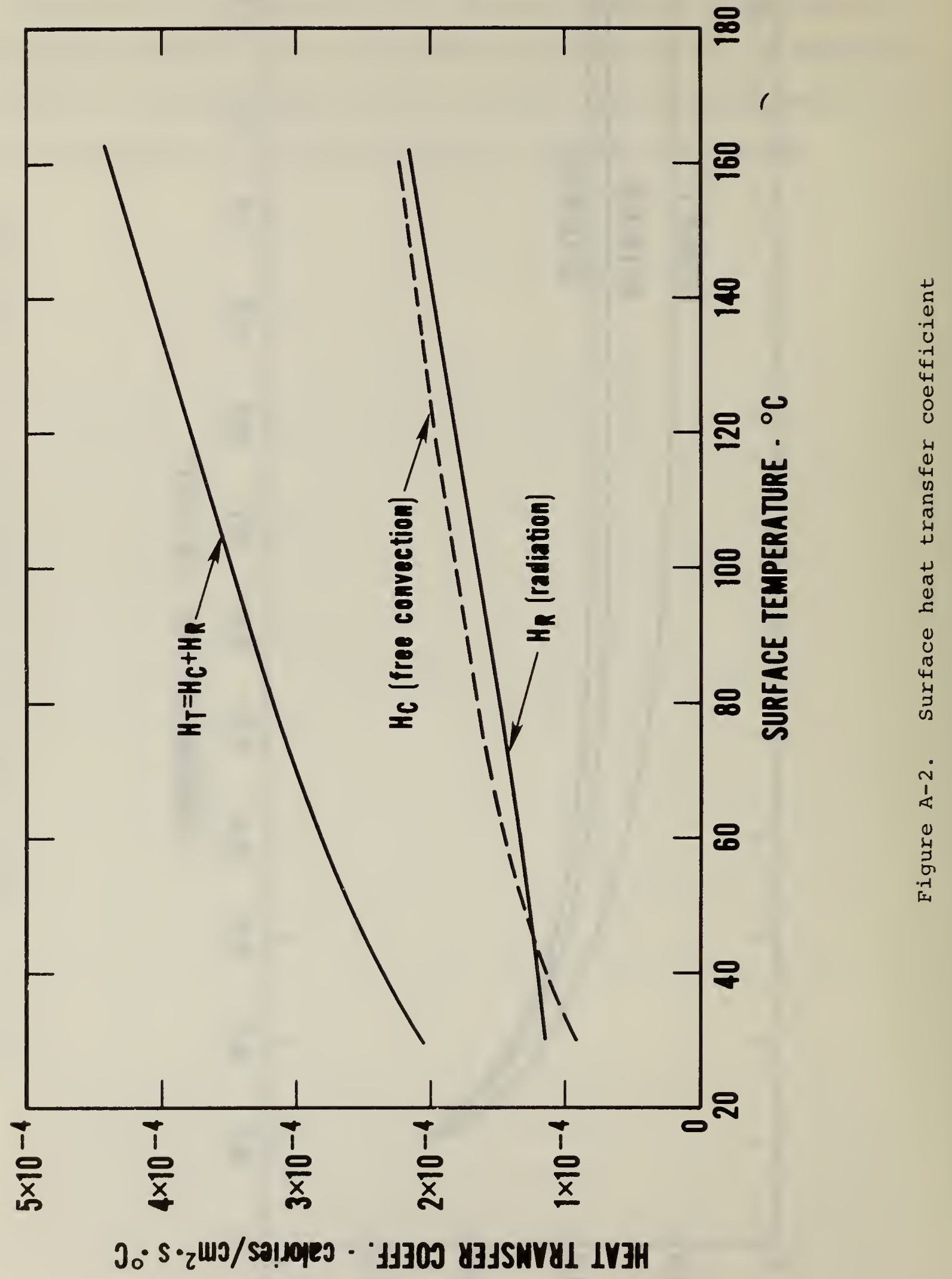




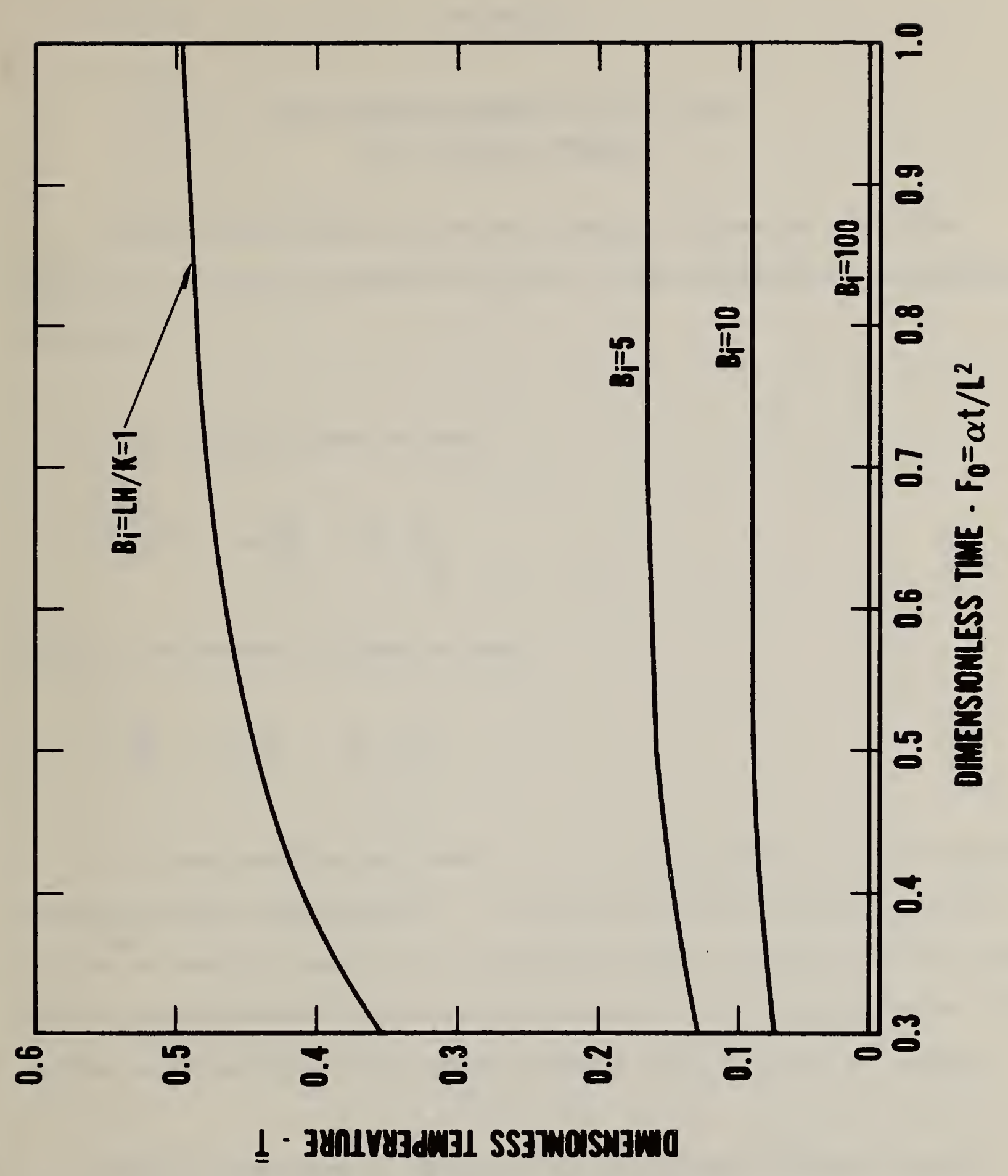

$\underset{+}{\stackrel{D}{E}}$

0

n

崩

0

4

녹

n

o

0

品

岂

n

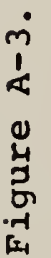

$\underline{1}$ - 3ynLyzd"z1 SSz7woswamo 



\section{RELATIONSHIP BETWEEN HOT PLATE TEST}

AND ADIABATIC FURNACE

In both the hot plate test and the adiabatic furnace the activation energy " $E$ ", and the pre-exponential factor "A" are calculated by semi-graphical procedure.

In the hot plate tests we have

$$
\ln \frac{\delta \mathrm{T}_{\mathrm{p}}^{2}}{\mathrm{r}^{2}}=\ln \frac{\mathrm{AE}}{\mathrm{KR}}-\frac{\mathrm{E}}{\mathrm{R}} \cdot \frac{1}{\mathrm{~T}}
$$

while in the adiabatic furnace we have

$$
\ln \frac{\mathrm{dT}}{\mathrm{d} t}=\ln \frac{\mathrm{A}}{\rho \mathrm{c}}-\frac{\mathrm{E}}{\mathrm{R}} \cdot \frac{1}{\mathrm{~T}}
$$

Both these equations are linear,i.e., are of the form $y=b+m x$ with the ordinates scaled logarithmically. In application the data from the test is plotted on semi-log paper and the activation energy is derived from the slope and the pre-exponential factor from the intercept. The equations may be calculated by the method of least squares using a hand calculator or computer.

Though the ordinates in equations (8) and (9) have different physical meanings, if we set the $x$-axis so that $1 / T$ coincides with $1 / T_{p}$, and adjust the scale for the y-axis for equation (8) so that the intercepts for the curves for both equation (8) and equation (9) occur at the same point, then the two lines will coincide. The assumptions in this analysis are that the 
phenomena measured in both tests are the same, that the activation energy and pre-exponential factor are the same as measured in both tests. Though these assumptions are only approximately satisfied the results which are discussed in the report are satisfactory.

Determination of ordinate scale.

From equation (1) at the intercept

$A=\frac{\delta T_{p}^{2}}{r^{2}} \cdot \frac{K R}{E}$

From equation (9) at the intercept $(1 / \mathrm{T}=0)$

$$
A=C \rho \frac{d T}{d t}
$$

therefore

$$
\frac{\delta \mathrm{T}_{\mathrm{p}}^{2}}{\mathrm{r}^{2}} \cdot \frac{\mathrm{KR}}{\mathrm{E}}=\mathrm{C} \rho \frac{\mathrm{dT}}{\mathrm{dt}}
$$

or

$$
\frac{\delta T_{p}^{2}}{r^{2}}=\frac{d T}{d t} \cdot C \rho \cdot \frac{E}{K R}
$$

Equation (13) locates the intercept for the hot plate equation at the same point as the intercept for the adiabatic furnace equation and the resulting hot plate equation is

$$
\ln \frac{\delta T_{p}^{2}}{r^{2}}=\ln \left(\frac{d T}{d t} \cdot C \rho \cdot \frac{E}{K R}\right)-\frac{E}{R} \cdot \frac{1}{T_{p}}
$$


inserting the values from the adiabatic furnace tests give

$$
\ln \frac{\delta \mathrm{T}_{\mathrm{p}}^{2}}{\mathrm{r}^{2}}=37.418-13273 \times \frac{1}{\mathrm{~T}_{\mathrm{p}}}
$$

The computation method is to select a thickness of insulation layer and assume a hot plate temperature. Next, using the Bowes-Townshend graph shown in figure B-1 determine $\delta_{c}$ and calculate $\delta_{c} \mathrm{~T}_{\mathrm{p}}^{2} / \mathrm{r}^{2}$. Substitute this last product into equation (15) and determine the corresponding $T_{p}$. Repeat the process with the new value of $T_{p}$ until convergence occurs. Usually only one or two iterations were necessary for convergence. The results are shown in figure B-2. 


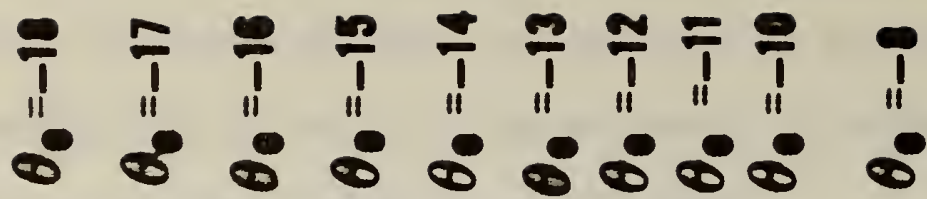

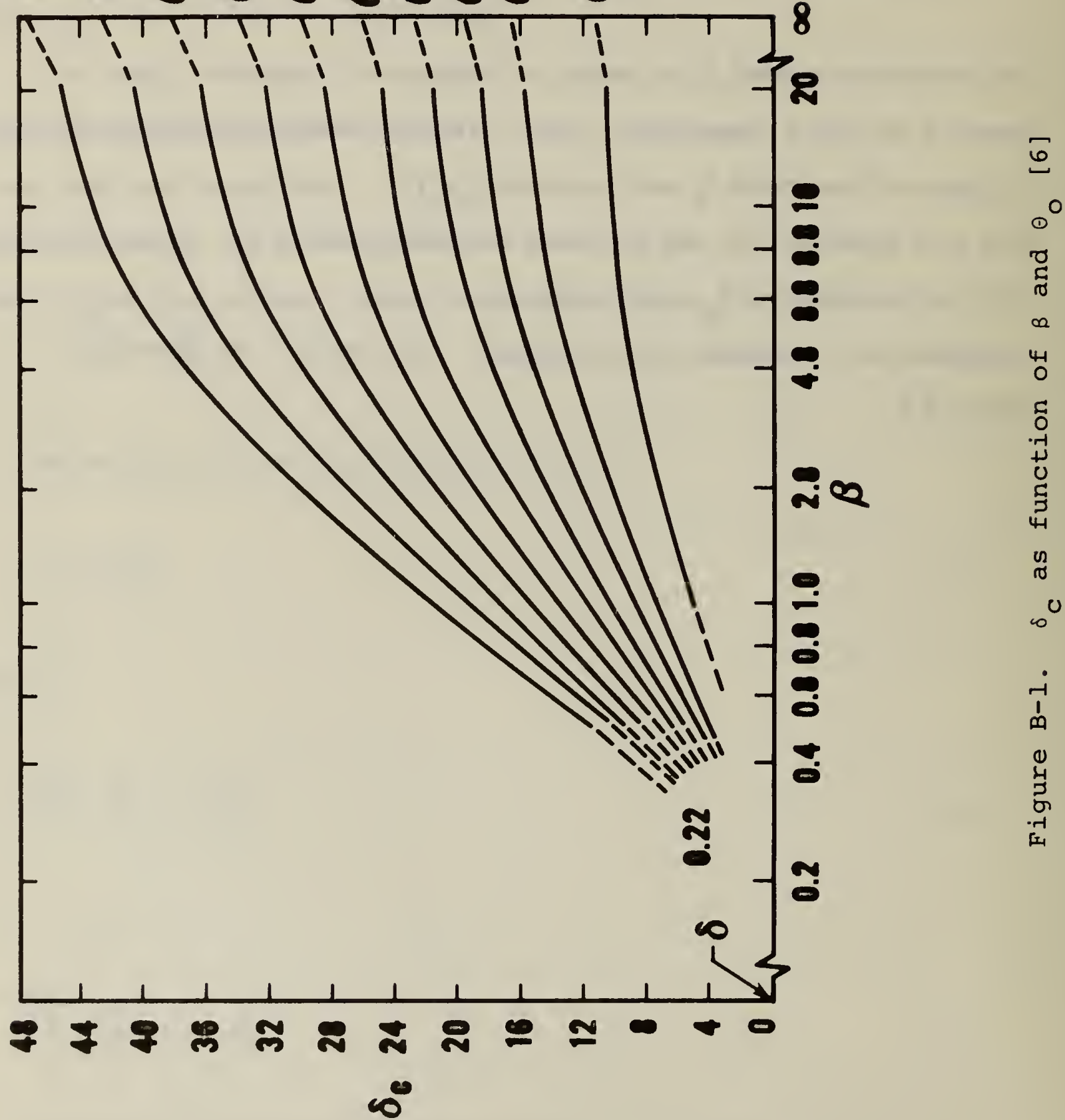


แง - SS3NYAH1 9MONOdS34Y0J

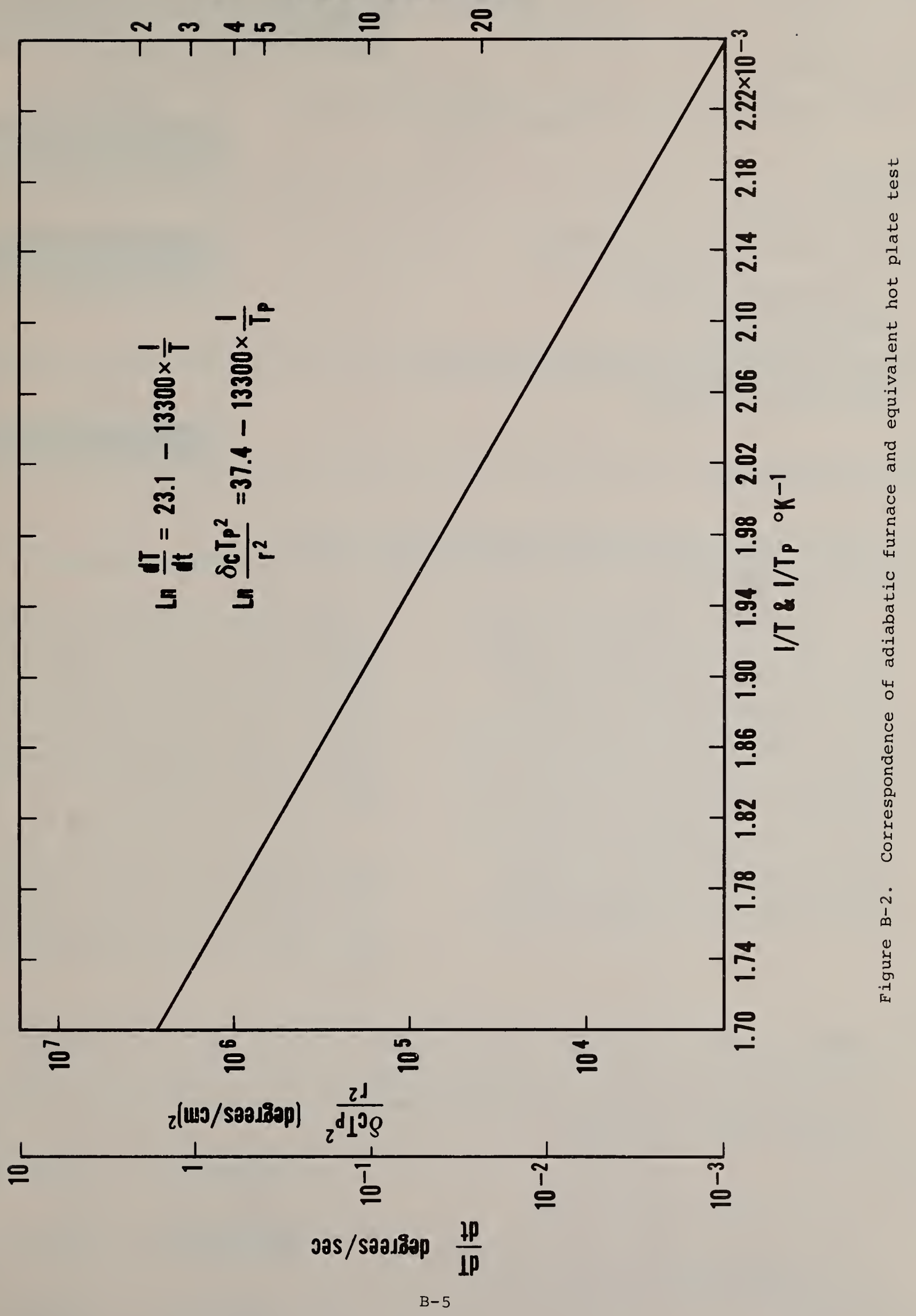


4. TITLE AND SUBTITLE

Fire Performance of Loose Fill Cellulosic Insulation in

Residential Occupancies - A Progress Report

August 1980

7. $A \cup T H O R(S)$

Lione1 A. Issen

8. Performing Organ. Report No.

9. PERFORMING ORGANIZATION NAME AND ADDRESS

NATIONAL BUREAU OF STANDARDS

DEPARTMENT OF COMMERCE

WASHINGTON, DC 20234

12. SPONSORING ORGANIZATION NAME AND COMPLETE ADDRESS (street, City, state, zIP)

Department of Energy

Washington, D.C. 20585

13. Type of Report \& Period Covered

Interim

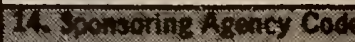

15. SUPPLEMENTARY NOTES

Document describes a computer program; SF-185, FIPS Software Summary, is attached.

16. ABSTRACT (A 200-word or less factual summary of most slgrificant Information. If document includes a significant blbliography or literature survey, mention it here.)

The smoldering and flame spread properties of cellulosic loose fill insulation were examined as a function of retardant type, particle size, and concentration to provide a basis for the development of improved fire test methods. A series of laboratory insulations was prepared whose fire performance covered an extended range of critical radiant flux in the attic floor radiant panel test and weight loss in the cigarette smoldering test. These materials were evaluated in a recessed light fixture test in a simulated attic configuration. Borax and boric acid were effective in raising the critical radiant flux (CRF) in the attic floor radiant panel test, but borax alone, in the cigarette smolder test, increased the smolderinf potential of loose fill cellulosic insulation. The divided box test for smoldering propagation dpptars to be a more realistic test than the present test for smoldering ignition.
In the cigarette sinoldering test, inclusion of $10 \%$ borax increased the poric acid requirement for passing from $7.5 \%$ to $20 \%$. In the attic floor radiant panel test, the finer the grind, the less boric acid required to meet Federal Specification HH-I-515D. This varied from less than $10 \%$ for vapor applied boric acid to over $35 \%$ for granular boric acid. Abov: the $25 \%$ level the presence of borax did not significantly affect the CRF level. Passing the recessed light fixture test required a minimum of $30 \%$ impalpable borfc acid, or $40 \%$ to $50 \%$ intermediate grind boric acld.

In order to determine fundamental parameters which could be used to characterize smoldering ignition potential, a number of test methods have been investigated which can be used to determine the pre exponential factor and the activation energy of ignition reaction. These include the Bowes and Townshend hot plate, thermo-gravimetric analysis (TGA), and the adiabatic furnace.

17. KEY WORDS (six to twelve entries; alphabotical order; capitalize only the first lettor of the flrat key word unloes a proper name; senaratar hu mamicolons)

Activation energy; borax; boric acid; cellulose; critical radiant flux; fire; fire retardants; fire tests; loose fill insulation; smoldering ignition; thermal analysis; thermal insulation.

18. AVAILABILITY DUnlimited

For Official Distribution. Do Not Release to NTIS

Order From Sup. of Doc., U.S. Government Printing Office, Washıngton, DC 20402, SD Stock No. SN003-003-

Order From National Technical Information Service (NTIS), Springfield, VA. 22161

\begin{tabular}{|l|l|}
\hline $\begin{array}{l}\text { 19. SECURITY CLASS } \\
\text { (THIS REPORT) }\end{array}$ & $\begin{array}{l}\text { 21. NO. OF } \\
\text { PRINTED PAGES }\end{array}$ \\
UNCLASSIFIED & 51 \\
\hline $\begin{array}{l}\text { 20. SECURITY CLASS } \\
\text { (THIS PAGE) } \\
\text { UNCLASSIFIED }\end{array}$ & 22. PrICe \\
\hline 7.00 \\
\hline
\end{tabular}



